Original Article

\title{
Intestinal Parasitic Infections among the Pediatric Patients in a Metropolitan City of Bangladesh with Emphasis on Cryptosporidiosis
}

Short Title: Pediatric Intestinal Parasitic Infections.

List of Authors and Affiliation

Nusrat Jahan Nipa ${ }^{1}$, Nasima Aktar ${ }^{2}$, Hasina Momotaj Hira ${ }^{3}$, Farhana Akter ${ }^{4}$, Dilshad Jahan ${ }^{5}$, Salequl Islam ${ }^{6}$, Ayukafangha Etando ${ }^{7}$, Kona Chowdhury ${ }^{8}$, Rahnuma Ahmad ${ }^{9}$, Mainul Haque $^{10}$

1. Nusrat Jahan Nipa. Email: nusratneepa@gmail.com. Orcid ID: https://orcid.org/0000-0002-7309-6766 Lecturer, Department of Virology, Chittagong Medical College (CMC), Chattogram, Bangladesh.

2. Nasima Aktar. Email: Nasima196177@yahoo.com. Orcid ID: https://orcid.org/00000002-0641-9596 Department of Microbiology, Chittagong Medical College (CMC), Chattogram, Bangladesh.

3. Hasina Momotaj Hira. Email: hira.sbmc33@gmail.com. Orcid ID: https://orcid.org/0000-0001-5435-7919 Department of Community Medicine, Abdul Malek Ukil Medical College (AMUMC), Noakhali, Bangladesh.

4. Farhana Akter. Email: fakter36@gmail.com Orcid ID: https://orcid.org/0000-00024488-9388 Department of Endocrinology, Chittagong Medical College, Chattogram 4203, Bangladesh.

5. Dilshad Jahan. Email: dilshad@asgaralihospital.com, Orcid ID: https://orcid.org/0000-0002-3939-9093, Department of Hematology, Asgar Ali Hospital, 111/1/A Distillery Road, Gandaria Beside Dhupkhola, Dhaka 1204, Bangladesh.

6. Salequl Islam. Email: salequl@juniv.edu. Orcid ID: http://orcid.org/0000-0001-

6131-4132. Professor, Department of Microbiology, Jahangirnagar University, Savar, Dhaka-1342, Bangladesh.

7. Ayukafangha Etando. Email: etta5013@gmail.com Orcid ID: https://orcid.org/00000001-5678-4121 Department of Medical Laboratory Sciences, Faculty of Health Sciences, Eswatini Medical Christian University, P.O Box A624, Swazi Plaza, Mbabane, Kingdom of Eswatini.

8. Kona Chowdhury. Email: konaonu96@gmail.com. Orcid ID: https://orcid.org/00000002-3836-1691 Department of Pediatrics, Gonoshasthaya Samaj Vittik Medical College and Hospital, Dhaka 1344, Bangladesh.

9. Rahnuma Ahmad. Email: rahnuma.ahmad@gmail.com Orcid ID: https://orcid.org/0000-0001-7379-0822 Department of Physiology, Medical College for Women and Hospital, Dhaka 1230, Bangladesh. 
10. Mainul Haque. Email: runurono@gmail.com. Orcid ID: https://orcid.org/0000-00026124-7993 The Unit of Pharmacology, Faculty of Medicine and Defence Health, Universiti Pertahanan Nasional Malaysia (National Defence University of Malaysia), Kem Perdana Sungai Besi, 57000 Kuala Lumpur, Malaysia.

\section{Original Article}

Intestinal Parasitic Infections among the Pediatric Patients in a Metropolitan City of Bangladesh with Emphasis on Cryptosporidiosis.

Short Title: Pediatric Intestinal Parasitic Infections.

\section{Abstract}

Background: Gastrointestinal parasitic infections are one of the global health concerns in developing countries like Bangladesh. Among them, Cryptosporidium spp. plays an essential role in causing diarrhea, malnutrition, and poor cognitive function, especially in children. The study was conducted to identify the frequency of cryptosporidium cases and other parasitic agents. Methods: A Cross-sectional observational study was conducted among 219 hospitalized children with diarrhea. The conventional microscopic technique was applied for parasitic detection. A particular staining procedure was performed to identify oocysts of Cryptosporidium spp. And PCR was conducted to determine the SSU rRNA and gp60 gene of Cryptosporidium. Results: Cyst of Giardia, ova of Ascaris lumbricoides (AL), Trichuris trichiura (TT), AL, and TT were identified in $2.3 \%, 1.4 \%, 0.5 \%$, and $0.9 \%$ samples by wet mount preparation. The distribution of Cryptosporidium spp. was $1.4 \%$ and $4.1 \%$, which was detected by the staining method and nested PCR. Factors independently associated with Cryptosporidium infection are unsafe water, lack of regular hand washing, and insufficiency of exclusive breastfeeding. Conclusions: This is the first report to detect the frequency of Cryptosporidium and other intestinal parasites and associated factors in Chattogram city of Bangladesh.

Keywords: Intestinal Parasitic, Contagions, Diseases, Pediatric Patients, Metropolitan City of Bangladesh, Cryptosporidiosis.

\section{Introduction}

Diarrhea is defined as the passage of three or more liquid or loose stools per day or if the individual experiences more frequent passage than usual [1-3]. It is categorized clinically as i) acute watery diarrhea, which persists for several hours or days [4], ii) persistent diarrhea that lasts for fourteen days or longer, and finally [5], iii) dysentery, blood, and mucous found in diarrheal stool $[6,7]$. Once diarrhea was one of the top deadly diseases [8, 9] and remains the second dominant cause of child mortality worldwide [10,11]. Almost 1.7 billion cases of childhood diarrheal diseases are diagnosed each year globally, resulting in the annual death of approximately 525,000 children under five, which is narrated around $63 \%$ of the global 
diarrhea burden [12]. Consequently, the acute diarrheal disease remains the top cause of morbidity and mortality among the pediatric population after a respiratory illness, especially in low-middle-income countries, and creates a serious public health issue [13, 14]. It is solely liable for one in eight deaths among children less than five years in Africa, Asia, and South America per annum, or a total of roughly 499,000 children every year are incriminated for diarrheal disease [13]. The far majority of which occurs in Sub-Saharan Africa, reflecting the highest child death rate in this region [14-16].

Only an episode of moderate-to-severe diarrhea has a significant repercussion on mortality and linear growth among survivors, facilitating the hazards of growth retardation, ill health, and cognitive impairment among the pediatric community [17-19]. Diarrheal diseases are a significant public health problem that affects children in developing countries where insufficient sanitation, hygiene, and portable water supply are the critical factors [13, 2025]. In Bangladesh, one-third of the total child death burden is due to this life-threatening disease, diarrhea [26-28]. Every year, a rural child suffers from 4.6 episodes of diarrhea on average, from which about 230,000 children die [26]. Therefore, it is essential to find out the etiology with the proper diagnostic procedure, and only then can successive intervention of the disease management be possible.

\section{Etiological Agents of Diarrhea}

The rotavirus is the most prevalent among numerous viral, bacterial, and parasitic agents causing pediatric diarrhea $[29,30]$. Some bacterial enteropathogens are also responsible for generating the same, such as Shigella, nontyphoidal Salmonella (NTS), Diarrhoeagenic E. coli (DEC), Vibrio Cholerae, Campylobacter, and Yersinia spp. [23, 31, 32]. Although enteric viruses and bacteria remain the predominant etiological agents [33-35], intestinal protozoal parasites are also significantly related to diarrheal disease in children, including Cryptosporidium spp., Giardia duodenalis Entamoeba histolytica, Blastocystis hominis, and Dientamoeba fragilis [36, 37].

\section{Cryptosporidium as a Protozoan Diarrheal Agent}

An intracellular Apicomplexan protozoan parasite belonging to the genus Cryptosporidium is accounted to be second only to rotavirus as the leading cause of moderate-to-severe diarrhea [38-40]. The organism attracted significance as one of the most prominent causes of diarrhea and diarrhea-causing death in young children, especially among the infant and immunodeficient individuals of developing countries worldwide [39, 41, 42]. As the annual detection rate of Cryptosporidium-ascribable cases is about 2.9-4.7 million in children under 2 years, the sub-Saharan African and South Asian territories face tremendous challenges in combating this infection [43].

Various species of this parasite have been identified, distinguished from each other regarding host range and public health concern [42]. Thus, Cryptosporidium, the ubiquitous $3 \mid$ Pag e 
coccidian parasite, has over 40 established species, and of these, 20 species and subtypes account for the vast majority of the human gastrointestinal infections worldwide. Additionally, C. homonis and C. parvum are the leading culprits causing cryptosporidiosis globally [44, 45]. Transmission occurs in fecal-oral, either by zoonotic or anthroponotic transmission. Cryptosporidium spp. has a low infective threshold with a robust oocyst that survives adequately in moist, ambient environments and is resistant to many commonly available disinfectants such as chlorine $[18,46]$.

\section{Effects of Cryptosporidiosis}

Diarrhea associated with cryptosporidiosis has been linked to three fundamental mechanisms [39, 47, 48]: 1) osmotic diarrhea caused by malabsorption [49, 50]; 2) parasiteinduced production of inflammatory products and host neurohumoral secretagogues [47, 48], and 3) secretory diarrhea caused by a parasite enterotoxin [51-53]. Different absorptive and secretory characteristics exist in different parts of the gastrointestinal system [54]. In immunocompetent persons, the small intestine, principally the ileum, is the primary location of Cryptosporidium infection. However, in AIDS patients, the gastrointestinal parasite distribution is more complex and extensive $[55,56]$.

The infection ranges from asymptomatic, self-limiting diarrhea to chronic [57-59]. The disease's intensity depends on the individual host's age, nutrition, and immune status [18]. The disease disrupts the intestinal epithelium, impairs the absorptive and barrier function of the small intestine, initiates prolonged (7-14 days) and persistent ( $\geq 14$ days) diarrhea $[18,60]$. Though cryptosporidiosis is a self-limiting disease in immunocompetent individuals, the aftermath of this illness has far-reaching threatening hazards beyond diarrheal consequences. It also interferes with nutrient absorption, resulting in chronic malnutrition, poor growth, and premature mortality, especially in developing countries $[37,61]$. Despite enlisting Cryptosporidium in its "Neglected Disease Initiative 2004" by WHO, it's one of the significant causes of diarrhea in pediatric children [62]. Several factors are related to this infection, such as host, environmental, and parasite species. Long-term contact with domestic animals, overcrowded places, poverty, poor sanitation, contaminated water sources, the immune status of the individual, and malnourishment of the children also play a dire role in this infection [40]. Recent studies highlight a reduction in overall diarrheal episodes in Bangladesh by improving water sources and sanitation behavior. Still, cryptosporidiosis and growth faltering, a recognized upshot of this infection, hasn't decreased at all $[63,64]$.

\section{Studies on Cryptosporidium}

Epidemiologic studies have demonstrated that Cryptosporidium is more prevalent in developing countries than developed countries [25, 39, 41, 65]. The organism has been reported as a substantial burden causing acute diarrhea [66]. A meta-analysis study on 
consequences of childhood diarrhea caused by this protozoan infection showed that in 2016, it was one of the fifth significant diarrheal etiological pathogens globally in children younger than 5 years, and acute infection attributed to more than 48000 deaths, and more than 4.2 million disability-adjusted life-years lost [18]. The significance of this intestinal parasite can easily be realized by the current Global Enteric Multicentric Study (GEMS) done on children from seven Asian and African countries where 9,439 were moderate-to-severe diarrheal cases and 13,129 control subjects, unveiling four exclusive moderate-to-severe diarrhea-causing agents namely Rotavirus, Cryptosporidium, Enterotoxigenic Escherichia coli, and Shigella [67].

In a longitudinal cohort study on 392 Bangladeshi slum-dwelling children (in the first two years of life) performed from 2008 to 2014, Cryptosporidium infection was reported to be very common (77\%). The study also highlights a close correlation between poverty and stunted growth during the first two years of life [40]. A survey of over 423 fecal samples from 185 children (up to five years) in an urban slum area of Bangladesh was done, and Cryptosporidium oocyst was detected in $9.2 \%$ cases, where the infection was highest among the children aged less than two. Moreover, that study also observed the infection decreases with age [68]. In a prospective study, fecal samples from children under 16 years attending an outpatient clinic in Cambodia were examined for Cryptosporidium, where these protozoan oocysts were detected in $2.2 \%$ to $7.7 \%$ cases [60]. In Tehran, a study was done in which stool samples from below 12 years old children with diarrhea were collected, and $1.1 \%$ of cases were found positive with this infection [66]. Another Iranian study reported that Cryptosporidium oocysts were detected in $3.8-8 \%$ of pediatric cases and immunocompromised patients, respectively [67].

\section{Diagnostic Modalities}

The diagnostic procedure comprises the microscopic examination of the fecal sample by wet mount and staining by modified Ziehl-Neelsen (mZN) staining [68] or auramine-phenol staining technique [69]. Direct and indirect immunofluorescence assays are expensive, but oocysts are readily identified [47, 70]. An immunological method (EIA, ELISA, and ICT) provides good sensitivity over microscopy but has drawbacks like false-positive results and is unavailable in developing countries due to cost ineffectiveness [71-73]. Though commonly used and cost-effective, the microscopic procedure is labor incentive and much timeconsuming, and the process exclusively relies on an individual's skill and experience [56,74]. Moreover, molecular methods are extensively used for genotyping and molecular epidemiological studies because of their higher sensitivity (detection ranges from 1-10 oocysts) over the traditional microscopic and immunological procedure $[44,75,76]$.

Various genes of Cryptosporidium are documented targeting its species [77], such as small subunit rRNA (SSU rRNA), Cryptosporidium outer wall protein (COWP), 70-kDa heat shock protein (HSP 70), thrombospondin-related adhesive protein (TRAP-C2), dihydrofolate 
reductase (DHFR) and actin genes [44, 78-80]. SSU rRNA and gp60 are the most common genetic markers for Cryptosporidium species identification and subtype determination, respectively [81-83]. The SSU rRNA gene is considered enormously used in genotypic differentiation between infections belonging to both humans and animals. In addition, the 60-kDa glycoprotein (gp60) gene possesses highly variable regions that permit a good deal of intraspecies sequence heterogenicity. These sites are crucial to determining many $C$. parvum and $C$. homonis subspecies $[44,56]$. The majority of the pathogenic strains are detected by nested assay, which is also chosen for identifying the negligible amount of oocyst $(<100)$ in the specimen [56].

As the parasite has a long-term detrimental effect on childhood growth, nutrition, and cognitive function with no appropriate drug or vaccine strategy, study on this parasite carries much importance. To date, no such research was previously done in Chattogram city. Hence, this study was designed to detect this pathogen and other parasites as a parasitic etiological cause of diarrhea in pediatric patients in this metropolitan city.

In the current study, microscopy by wet mount preparation, concentration technique (formol-ether sedimentation technique), and staining procedure (mZN) were applied to all samples. Later on, nested PCR was performed targeting SSU rRNA and the gp60 gene. The study would help the clinician diagnose the case properly by exploring the actual etiology of protozoa-related diarrheal illness and indirectly minimizing the empirical use of antibiotics to treat parasitic diarrhea, thus reducing the Multi-Drug Resistant problem in Bangladesh.

\section{Objectives of the Study}

i. To identify intestinal parasites microscopically by wet mount preparation. ii. To identify Cryptosporidium microscopically by mZN staining technique. iii. To detect the presence of Cryptosporidium spp. by nested Polymerase Chain reaction. iv. To compare the result of microscopy with that of PCR.

\section{Materials and Methods}

Study Design: This was a cross-sectional observational study. Place of Study: Department of Microbiology, Chittagong Medical College, Chattogram, Bangladesh and Department of Pathology and Parasitology, Chittagong Veterinary and Animal Sciences University (CVASU), Chattogram, Bangladesh. Study Period: The study was carried out from July 2019 to June 2020.

Study Population: Indoor and outdoor pediatric diarrheic patients of Chittagong Medical College Hospital and Chattogram Maa-O-Shishu Hospital Medical College, Chattogram, Bangladesh. 
Eligibility Criteria

Inclusion Criteria: The study was conducted on Indoor and outdoor pediatric patients (up to 18 years) suffering from acute watery and persistent diarrhea ( $\geq 14$ days) irrespective of their social status, who agreed or whose guardians had the consent to enroll their children after full explanation of the study objectives. Exclusion Criteria: The study precluded the pediatric patients having bloody diarrhea (with blood and mucous in it) and the adult patients. Moreover, the patients or guardians who were unwilling to sign the assent form were excluded. The macroscopic Study plan is illustrated in Figure 1.

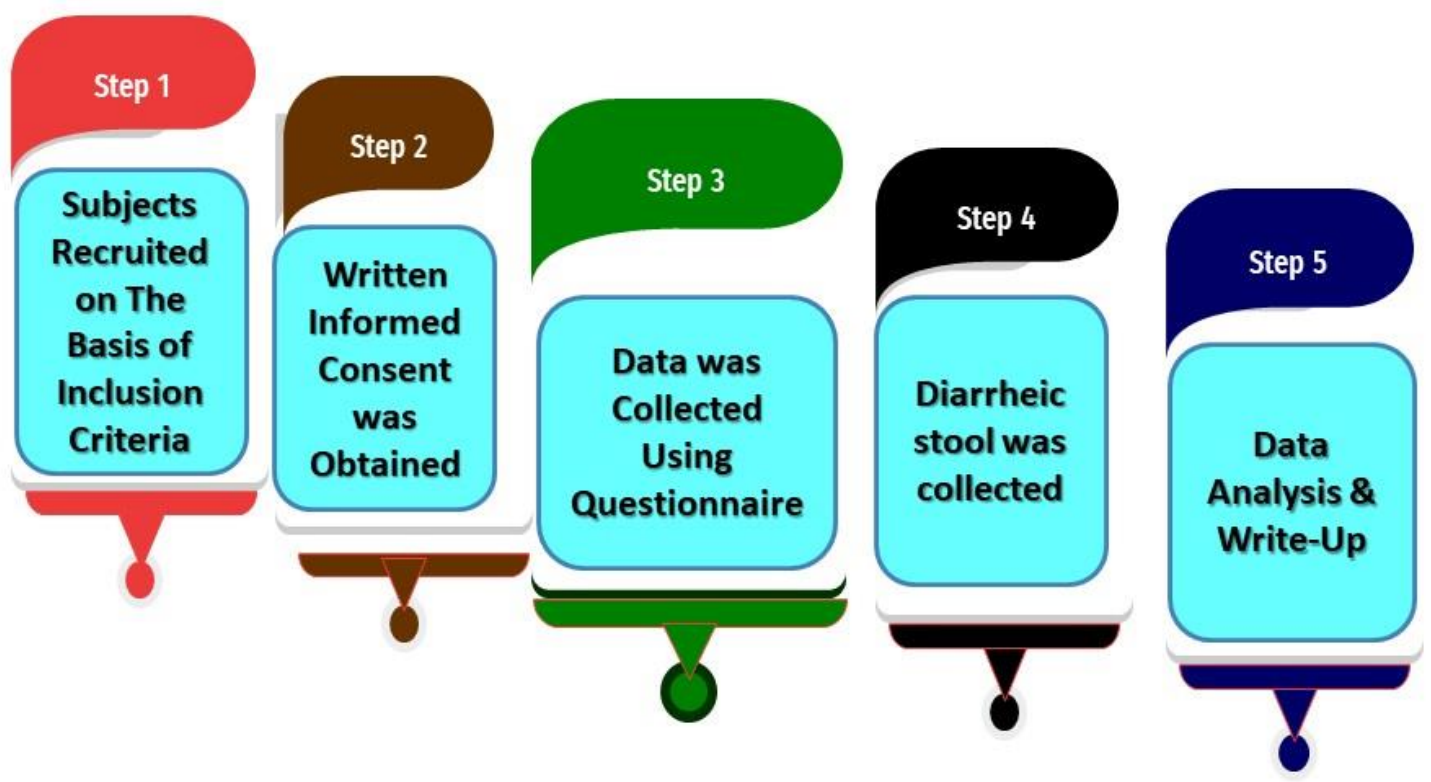

Figure 1: A Flow Chart Depicting Macroscopic Study Plan.

Ethical Approval

This study received ethical approval [Reference No.: CMC/PG/2019/592, Dated November 3, 2019] from the Institutional Review Board of Chittagong Medical College Hospital ( $\mathrm{CMCH}$ ) 57 K.B. Fazlul Kader Rd, Chattogram 4203, Bangladesh. Participation and reporting included herein were hinged on consent forms signed by patients/guardians of the pediatric diarrheic patients (children up to 18 years) before administering the questionnaire. The respondents were informed correctly using the participant's information sheet about their rights and all the relevant aspects of the study, including its aim and interview procedure. No patient was older than 18 years.

Study Sample

Diarrheal stool. 
Sample Size

$\mathrm{n}=\frac{z 2 p q}{d 2}$

$=123.2$

Where $\mathrm{n}$ is the sample size.

$z$ is the confidence interval (95\%) $z=1.96$.

$p$ is the pre-estimated prevalence of $9.2 \%$ obtained from a study performed by Ahmed in Dhaka [84], Bangladesh.

$d$ is a marginal error (5\%).

$\mathrm{n}=(1.96)^{2} \times 0.092 \times 0.908 /(0.05)^{2}$

$=123.17$

This means a minimum of 123 participants need to participate in this study.

Sampling Technique

Nonprobability, purposive type of sampling.

Preparation of Questionnaire

The questionnaire was prepared and accustomed from the study by Tombang, Cameroon [85]. The questionnaire was modified under the study's eligibility criteria and Bangladeshi cultural aspects. The questionnaire was comprised of a few segments. In the first segment, particulars of the patients were included; then, socio-demographic history, habitual elements, and clinical features were incorporated.

\section{Data Collection}

Indoor and outdoor diarrheic pediatric age group patients in some selected tertiary hospitals were selected. Informed written consent from patients or legal guardians was obtained after a full explanation of the outcome and purpose of the study. After taking consent, the patient's history details, including demographic information and clinical findings, were recorded in a predesigned case record form. Then stool sample was collected in a clean, leak-proof, wide-mouth container.

\section{Method of Sample Collection}

The sample was collected in a clean, leak-proof, wide-mouth container appropriately labeled with the patient's name, age, time of collection, and identification number. Then it was transported to the Department of Microbiology, and some portions of each sample were transferred to the Eppendorf tube and refrigerated at $-80 \circ \mathrm{C}$ to perform the molecular method [86]. Again, the rest of the sample was taken into two containers. One container contained a $10 \%$ formalin preserved fecal sample for direct wet mount preparation, and the other retained an unpreserved fecal sample. Afterward concentration procedure was followed with this unpreserved sample before the staining procedure. 
Laboratory Procedure

All samples were undergone to wet mount preparation by both saline and iodine preparation and staining by mZN staining Figure 2 and Figure 3. A fecal smear was made from a concentrated stool sample on a clean, grease-free glass slide. After fixation, mZN staining was done, and the slide was examined under a microscope using oil immersion. Cryptosporidium oocysts were identified as red, small (4 to $6 \mu \mathrm{m}$ ) sized, characteristically round or slightly ovoid, acid-fast oocyst against a blue background [87].

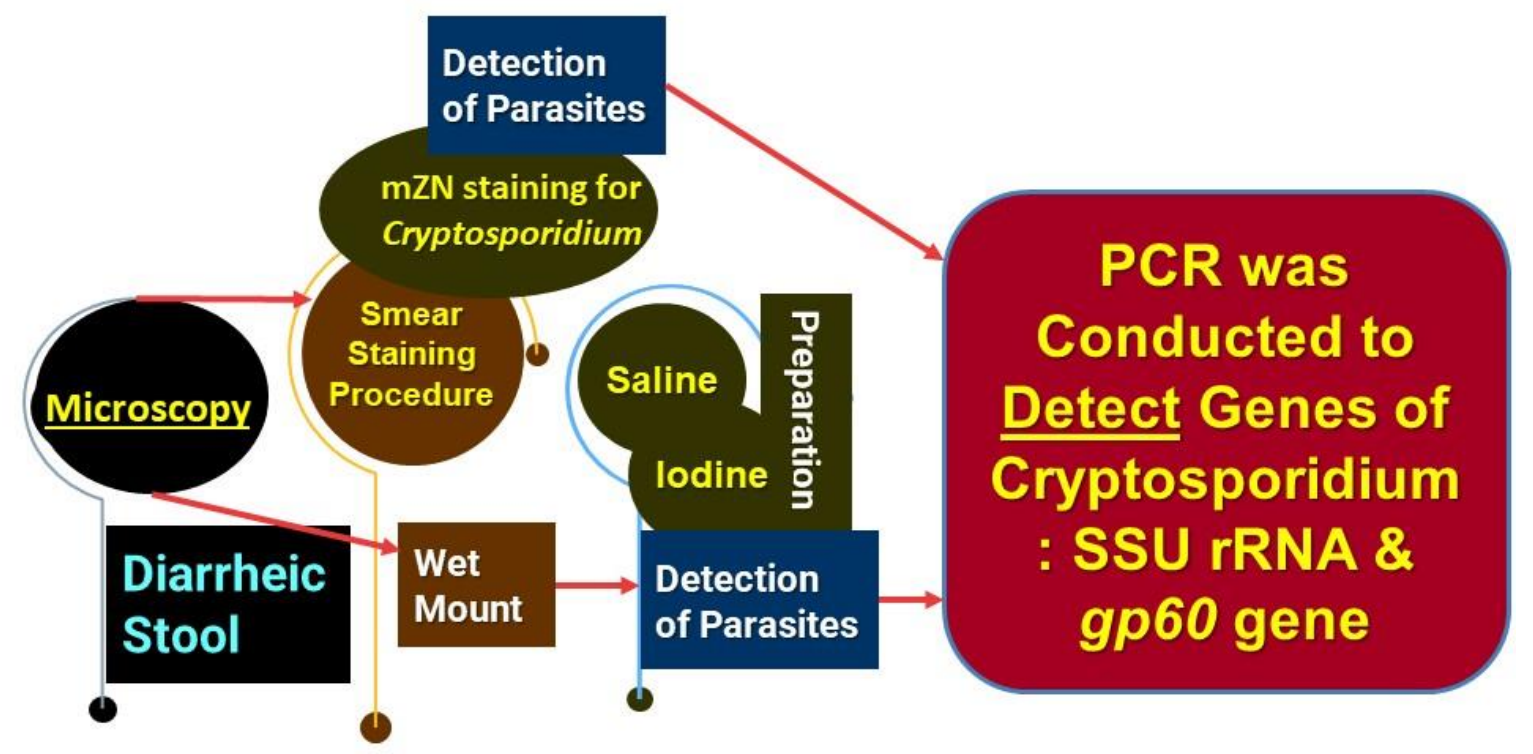

Figure 2: Illustrating the Steps of Laboratory Methods [31].

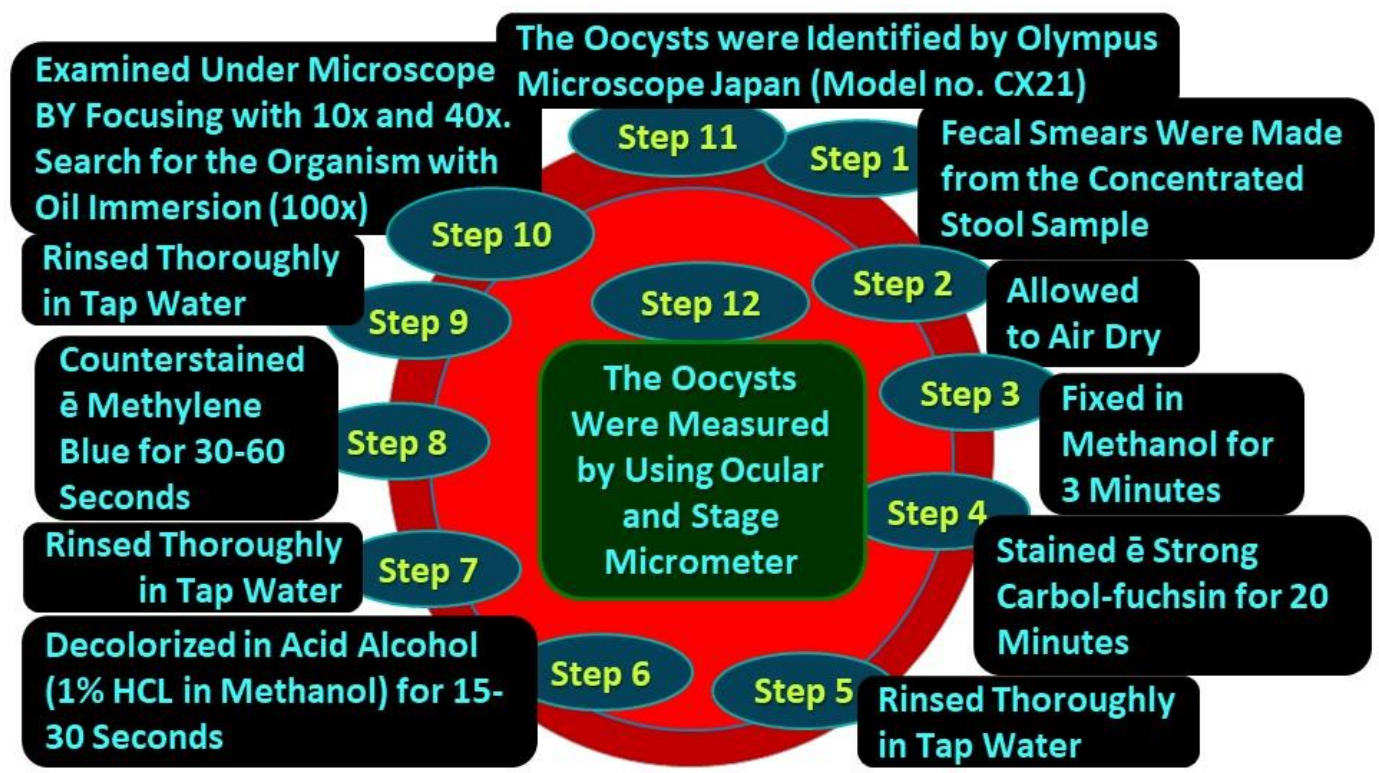

Figure 3: Illustrating the Steps of Modified Ziehl-Neelsen Stain [31]. 
The Procedure of Polymerase Chain Reaction (PCR)

Process of DNA Extraction

DNA extraction was done as per the manufacturer's instruction by The Invitrogen PureLink Microbiome DNA Purification kit (Thermo Fisher Scientific), and the procedure was performed at room temperature $\left(20-25^{\circ} \mathrm{C}\right)$. The purified DNA in the tube was preserved at $20^{\circ} \mathrm{C}$ for further use.

Primers used for SSU rRNA and gp60 gene ${ }^{31}$ are listed in Table 1.

For the SSU rRNA gene, the first pair of primers (Table 1) were used as first-round PCR to amplify the $830 \mathrm{bp}$ sequence of the SSU rRNA gene, and the second pair of primers (Table 1) were used for second-round PCR to amplify a 240 bp sequence. For the gp60 gene, first set primers (Table 1) were used as first-round PCR to amplify the 412 bp sequence, and the next pair of primers (Table 1) were used for second-round PCR to amplify the 350 bp sequence of the gp60 gene.

Preparation of Reaction Mixture

Sterile micro-centrifuge tubes $(1.5 \mathrm{ml})$ were taken and labeled with the date and identification number. Primer tubes were centrifuged for a few seconds. Then it was vortexed for 15 seconds and finally diluted with nuclease-free water to make a 1:10 dilution. For each sample, a total of $20 \mu \mathrm{l}$ of the mixture was prepared by mixing $10 \mu \mathrm{l}$ of master mix (mixture of dNTP, Taq Polymerase, $\mathrm{MgCl}_{2}$, and PCR buffer), $1 \mu \mathrm{l}$ forward primer, $1 \mu \mathrm{l}$ of reverse primer, $2 \mu \mathrm{I}$ DNA template and $6 \mu$ l of nuclease-free water.

Table 1: Primers used for SSU rRNA gene and gp60 gene of Cryptosporidium species.

\begin{tabular}{|c|c|c|c|c|}
\hline & & $\begin{array}{c}\text { Primer } \\
\text { name }\end{array}$ & Primer sequence $\left(5^{\prime}-3^{\prime}\right)$ & Size \\
\hline \multirow{4}{*}{$\begin{array}{l}\text { SSU rRNA } \\
\text { gene }\end{array}$} & \multirow[t]{2}{*}{$\begin{array}{l}\text { First Set } \\
\text { Primer }\end{array}$} & XF2 & $\begin{array}{l}\text { F- } \\
\text { GGAAGGGTTGTATTTATTAGATAAAG }\end{array}$ & \multirow{2}{*}{$\begin{array}{l}830 \\
b p\end{array}$} \\
\hline & & XR2 & R-AAGGAGTAAGGAACAACCTCCA & \\
\hline & \multirow{2}{*}{$\begin{array}{l}\text { Second Set } \\
\text { Primer }\end{array}$} & PSSUf & F-AAAGCTCGTAGTTGGATTTCTGTT & \multirow{2}{*}{$\begin{array}{c}240 \\
b p\end{array}$} \\
\hline & & PSSUr & R-ACCTCTGACTGTTAAATACRAATGC & \\
\hline \multirow{4}{*}{ gp60 gene } & \multirow{2}{*}{$\begin{array}{l}\text { First Set } \\
\text { Primer }\end{array}$} & gp15-ATG & F-ATGAGATTGTCGCCTCATTATC & \multirow{2}{*}{$\begin{array}{c}412 \\
b p\end{array}$} \\
\hline & & gp15-STOP & R-TTACAACACGAATAAGGCTGC & \\
\hline & \multirow{2}{*}{$\begin{array}{l}\text { Second Set } \\
\text { Primer }\end{array}$} & gp15-15A & F-GCCGTTCCACTCAGAGGAAC & \multirow{2}{*}{$\begin{array}{c}350 \\
b p\end{array}$} \\
\hline & & gp15-15E & R-CCACATTACAAATGAAGTGCCGC & \\
\hline
\end{tabular}




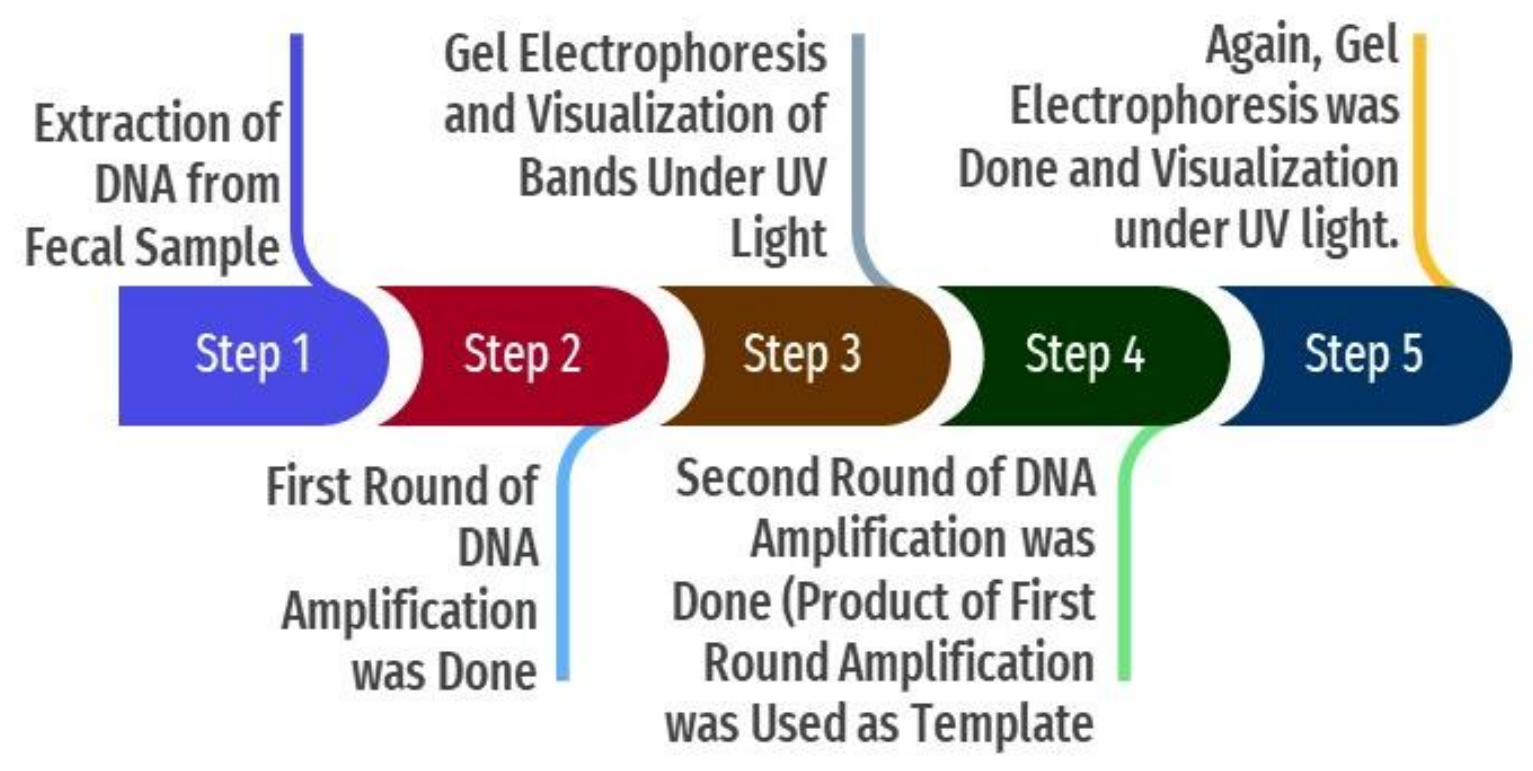

Figure 4: Flow Chart of Nested PCR.

SSU Gene of Cryptosporidium Species

$1^{\text {st }}$ Round PCR

Initial denaturation at $94^{\circ} \mathrm{C}$ for 5 min followed by 30 cycles of denaturation at $94^{\circ} \mathrm{C}$ for $45 \mathrm{~s}$, primer annealing at $45^{\circ} \mathrm{C}$ for 2 minutes,

extension at $72^{\circ} \mathrm{C}$ for 1.5 minutes and a

final extension at $72^{\circ} \mathrm{C}$ for $10 \mathrm{~min}$.

$2^{\text {nd }}$ round $P C R$

Initial denaturation at $94^{\circ} \mathrm{C}$ for 5 min followed by 35 cycles of denaturation at $94^{\circ} \mathrm{C}$ for the 30s,

primer annealing at $55^{\circ} \mathrm{C}$ for the $30 \mathrm{~s}$,

extension at $72^{\circ} \mathrm{C}$ for the $30 \mathrm{~s}$, and a

final extension at $72^{\circ} \mathrm{C}$ for 10 minutes.

gp60 gene

$1^{\text {st }}$ Round PCR

Initial denaturation at $94^{\circ} \mathrm{C}$ for 5 min followed by 35 cycles of denaturation $94^{\circ} \mathrm{C}$ for the $30 \mathrm{~s}$, primer annealing at $55^{\circ} \mathrm{C}$ for $45 \mathrm{~s}$, extension at $72^{\circ} \mathrm{C}$ for $1 \mathrm{~min}$ and a final extension of $72^{\circ} \mathrm{C}$ for $10 \mathrm{~min}$ $2^{\text {nd }}$ Round PCR

Initial denaturation $94^{\circ} \mathrm{C}$ for 5 min followed by 30 cycles of denaturation $94^{\circ} \mathrm{C}$ for the $30 \mathrm{~s}$, primer annealing at $55^{\circ} \mathrm{C}$ for the 30 s, 
extension at $72^{\circ} \mathrm{C}$ for the $30 \mathrm{~s}$, and a final extension at $72^{\circ} \mathrm{C}$ for 10 minutes.

In the nested PCR, the amplified product of the first round of PCR is used as the template. The second set of primers was added to the reaction mixture in the second amplification (nested PCR). The PCR reactions were conducted in a thermal cycler (Applied Biosystems 2720, MA).

The amplicon size was determined by comparing the position of the amplicon concerning that of a $100 \mathrm{bp}$ DNA ladder that was loaded in the adjacent well and simultaneously electrophoresis.

Interpretation

Samples were scored as PCR positive for Cryptosporidium spp., when PCR product of $240 \mathrm{bp}$ could be detected for SSU rRNA gene. Samples were detected as PCR positive for Cryptosporidium spp., when 350 bp could be seen for the gp60 gene.

Data Analysis

A questionnaire was used for each of the cases. A predesigned questionnaire systematically recorded all the relevant information (history), socio-demographic history, clinical findings, and laboratory findings of every case. The data were analyzed using the Statistical Package for Social Sciences (SPSS) version 25.0. Statistical analysis was done by standard statistical procedure; MS Excel prepared graphs and charts. The result was presented in tables and figures. A p-value $<0.001$ was considered significant.

\section{Results}

Distribution of The Study Population According to Their Age and Sex.

A total of 219 fecal samples were collected from pediatric diarrheic patients of two tertiary medical college hospitals. The age range of the patients was 2 months to 18 years old. At first, all samples were examined for the direct microscopic examination, then modified Ziehl-Neelsen staining, and afterward, nested PCR was done for specific target genes of Cryptosporidium. In the present study, age distribution shows that most of the study population belonged to the 1 to 5 years of age group (47\%) followed by $<1$ year of age group (30.1\%) (Table 2). Among them, 125 (57\%) were male, and 94 (43\%) were female. The male to female ratio was about 1.33:1. 
Table 2: Distribution of the Study Population by their Age $(n=219)$.

\begin{tabular}{lcc}
\hline $\begin{array}{c}\text { Age } \\
\text { Group }\end{array}$ & Frequency & $\begin{array}{c}\text { Percentage } \\
(\%)\end{array}$ \\
\hline$<1$ & 66 & $30.1 \%$ \\
$1-5$ & 103 & $47.0 \%$ \\
$6-10$ & 37 & $16.9 \%$ \\
$11-15$ & 11 & $5.0 \%$ \\
$15-18$ & 02 & $0.9 \%$ \\
\hline Total & 219 & $100 \%$ \\
\hline
\end{tabular}

Microscopic Assay

a) Wet Mount Preparation: All fecal samples were first examined for direct microscopic examination by both saline and iodine preparation. Table 3 showed wet mount findings among 219 study samples where Giardia was found positive in 5 (2.3\%) samples. Moreover, other parasites like helminthic eggs were found in some samples. Ova of Ascaris lumbricoides 3 (1.4\%), Trichuris trichiura 1 (0.5\%) and mixed infection 2 (0.9\%) were detected.

Table 3: Detection of the Parasite by Wet Mount in the Study Population $(n=219)$.

\begin{tabular}{ccc}
\hline Parasites & Frequency & $\begin{array}{c}\text { Percentage } \\
\text { (\%) }\end{array}$ \\
\hline Giardia & 05 & 2.3 \\
A. lumbricoides & 03 & 1.4 \\
T. trichiura & 01 & 0.5 \\
A. lumbricoides \& T. trichiura & 02 & 0.9 \\
No parasite & 208 & 95 \\
\hline Total & 219 & 100 \\
\hline
\end{tabular}

b) Identification of Cryptosporidium by mZN Staining: The microscopic examination of the stool samples through mZN staining showed the presence of Cryptosporidium oocysts (Figure 4) in 3/219 (1.4\%) samples (Table 4). 


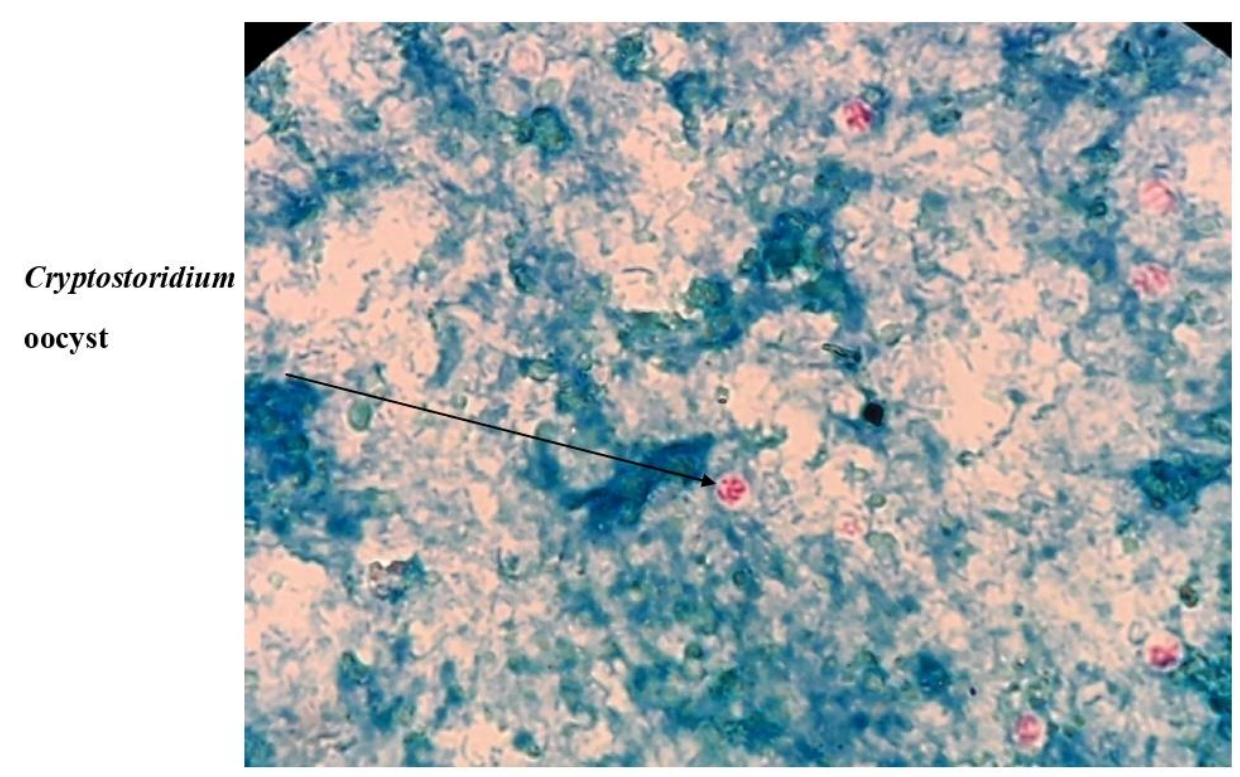

Figure 5: Cryptosporidium oocyst in mZN Stain.

Table 4: Association of microscopic findings of Cryptosporidium with nested PCR ( $n=219)$.

\begin{tabular}{lcccc}
\hline \multicolumn{1}{c}{ Microscopic findings } & \multicolumn{2}{c}{ Nested PCR findings } & Total $\begin{array}{l}\mathrm{p} \\
\text { value }\end{array}$ \\
\cline { 2 - 3 } & & $(+\mathrm{ve})$ & & \\
\hline Modified Ziehl- & & & & \\
$\begin{array}{l}\text { Neelsen staining } \\
\text { Cryptosporidium (+ve) }\end{array}$ & 03 & $00(0.0 \%)$ & 03 & \\
Cryptosporidium (-ve) & $(33.3 \%)$ & 210 & 216 & $<0.001$ \\
& 06 & $(100 \%)$ & & \\
\hline \multicolumn{1}{c}{ Total } & 09 & 210 & 219 & \\
\hline
\end{tabular}

Notes: $p$ value derived from chi-square test. Figures within parentheses indicate the percentage.

Nested PCR Findings

Nested PCR detected Cryptosporidium oocysts in 9 (4.1\%) samples (Figure 4). The bands of SSU-rRNA (240 bp) and gp60 genes (350 bp) were shown in Figures 5 and 6, respectively. 


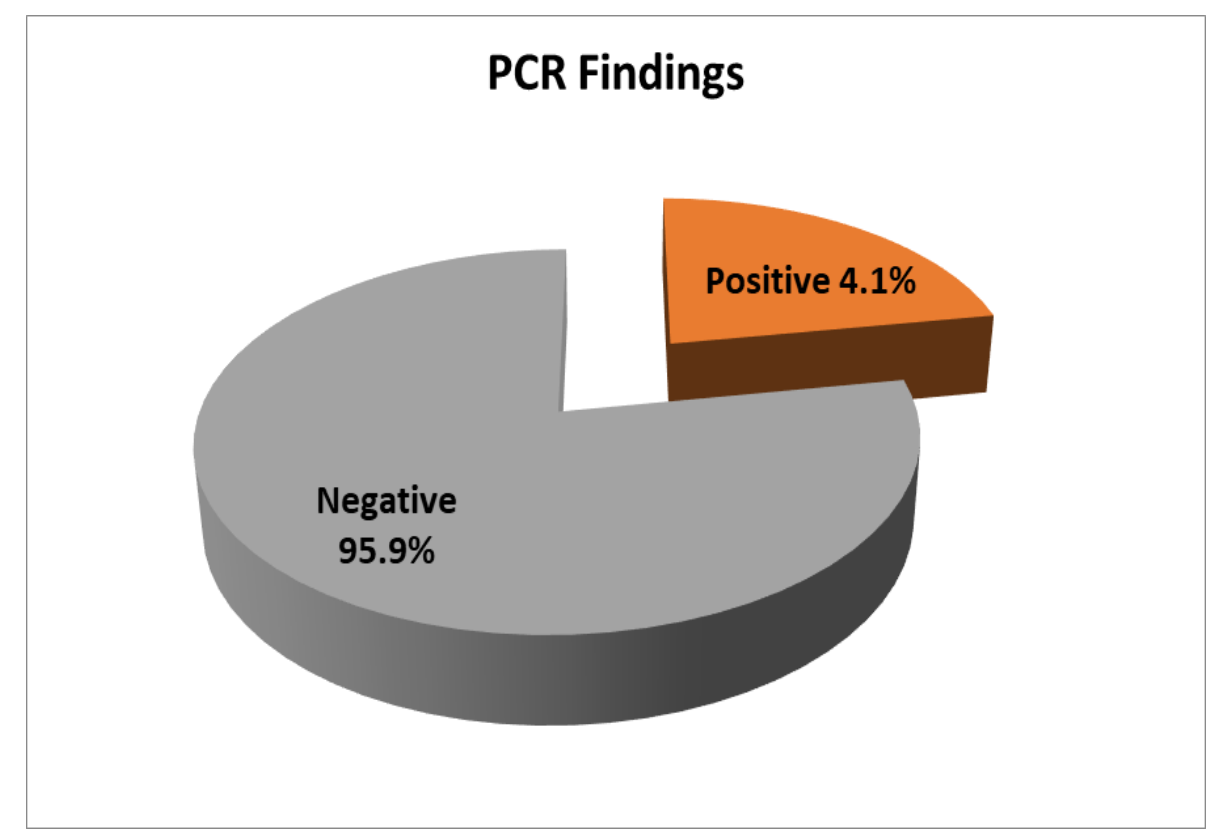

Figure 6: Distribution of Cryptosporidium spp. by nested PCR $(n=219)$

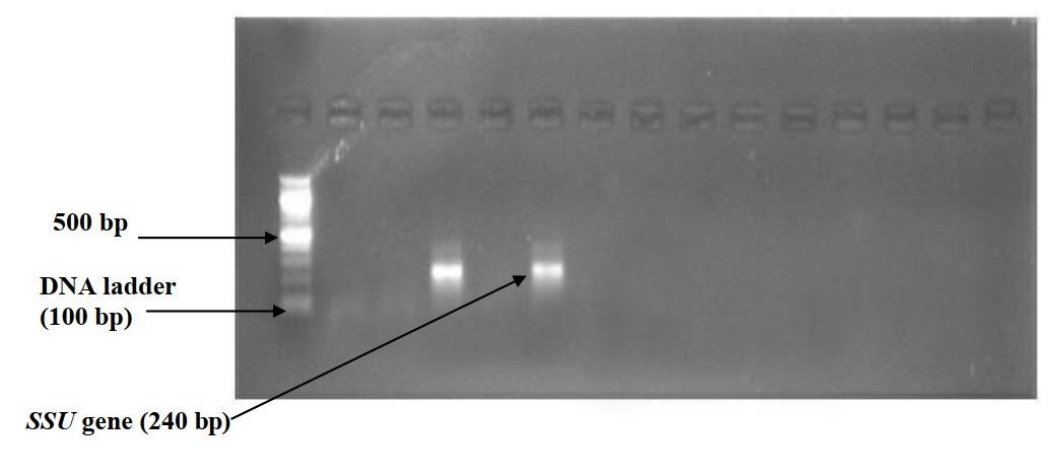

Figure 7: Bands of amplified DNA of Cryptosporidium spp.

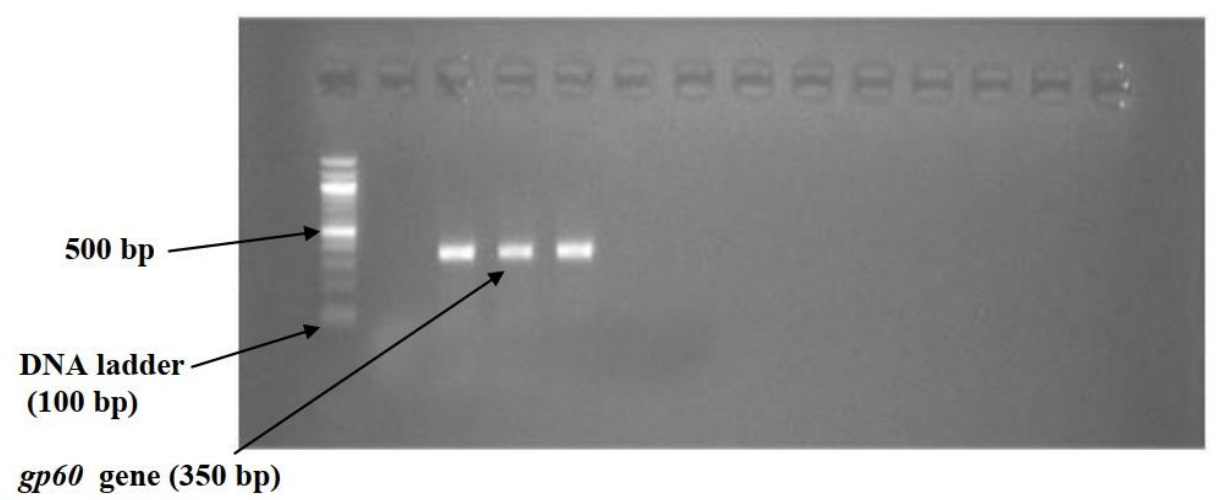

Figure 8: Bands of amplified DNA of Cryptosporidium spp. 
Frequency of Cryptosporidium in different Age and Sex Groups.

The prevalence of Cryptosporidium spp. was more in the 1-5 years' age group, and male predominance was observed, but both were statistically non-significant.

Association of Microscopic Findings with that of Nested PCR.

Table 4 shows the association between microscopic and nested PCR findings of Cryptosporidium. Here Chi-square test was done, and it was found to be highly significant statistically $(p<0.001)$.

Sensitivity, Specificity of Cryptosporidium Spp. Microscopy

The sensitivity and specificity of Cryptosporidium Spp. Microscopy was found to be $33.3 \%$ and $100 \%$, respectively, taking the PCR method as the gold standard.

Associated Factors for Parasite Infestation

Most of the study population (64.8\%) drink safe water, and $70.3 \%$ use regular hand washing.

Multivariate Logistic Regression to Determine the Independent Factors Associated with Cryptosporidium Infection

Table 5 summarizes the risk factors associated with cryptosporidiosis, including male gender, unsafe drinking water, irregular hand washing, rural residence, insufficiency of exclusive breastfeeding, and history of having pets. It reflected the use of unsafe drinking water $(\mathrm{OR}=0.255, \mathrm{P}=0.043)$, lack of regular hand washing $(\mathrm{OR}=0.109, \mathrm{P}=0.001)$, and insufficiency of exclusive breastfeeding $(\mathrm{OR}=0.261, \mathrm{P}=0.047)$ were independently associated with Cryptosporidium infection. But other factors like male gender ( $\mathrm{OR}=0.938, \mathrm{P}=0.925)$, rural resident $(\mathrm{OR}=0.335, \mathrm{P}=0.097), \mathrm{H} / \mathrm{O}$ having a pet $(\mathrm{OR}=2.26, \mathrm{P}=0.251)$ have no significant association with the infection.

Table 5: Multivariate Logistic Regression to determine the independent factors associated with Cryptosporidium infection.

\begin{tabular}{lcccc}
\hline Variables & Adjusted OR & \multicolumn{2}{c}{$95 \% \mathrm{Cl}$} & \multirow{2}{*}{ P value } \\
\cline { 3 - 4 } & & Lower & Upper & \\
\hline Male gender & 0.938 & 0.245 & 3.591 & $0.925^{\text {ns }}$ \\
Unsafe drinking water & 0.255 & 0.062 & 1.051 & $0.043^{\mathrm{s}}$ \\
Irregular hand washing & 0.109 & 0.022 & 0.540 & $0.001^{\mathrm{s}}$ \\
Rural resident & 0.335 & 0.087 & 1.290 & $0.097^{\text {ns }}$ \\
Insufficiency of exclusive breast feeding & 0.261 & 0.063 & 1.074 & $0.047^{\mathrm{s}}$ \\
H/O having pet & 2.263 & 0.542 & 9.455 & $0.251^{\text {ns }}$ \\
\hline
\end{tabular}

$\mathrm{Cl}=$ Confidence interval, $\mathrm{OR}=$ Odds ratio, $\mathrm{s}=$ Significant, $\mathrm{ns}=$ Not significant 
The bar diagram shows the distribution of Cryptosporidium spp. by nested PCR; among 219 samples, 9 (4.1\%) were Cryptosporidium positive.

\section{Discussion}

Intestinal parasites such as Cryptosporidium spp. along with other parasites are liable for diarrhea, especially among children in developing countries [89]. Though infections due to these parasites are self-limiting in immunocompetent individuals, chronicity often results in malnutrition, growth faltering, and cognitive function impairment, especially in children [9095]. Because of these alarming effects on a child's health, it draws attention to find out the incidence of protozoan parasites responsible for childhood diarrheic disease.

In our study, $2.3 \%$ cases were found Giardia positive by wet mount preparation among 219 samples. The prevalence of Giardia infection among 0-15 years Portuguese children was $1.9 \%$ when estimated by direct microscopic examination. Nevertheless, when monoclonal ELISA techniques were utilized, the rate increased to 6.8\% [96]. Furthermore, the higher rate (7.8\%) of Giardia infestation was found in the younger group (0-5 years), and there was no difference observed between sexes [96]. A study among pediatric patients (<5years) in a tertiary hospital was done where Giardia cysts were found in $4.14 \%$ of cases [97]. In a slum area of Bangladesh, Giardia positive samples were found in $6.01 \%$ cases among the schoolgoing children [98]. In Sikkim of India, a prospective study among symptomatic children (<15 years) was done where Giardia cysts were found in $5 \%$ of cases by wet mount [99]. About $8.2 \%$ of patients were positive for giardiasis through the direct smear method in Kashmir Valley, India [100]. Another study in Lucknow of India showed that Giardia was detected $15.5 \%$ by immediate wet mount preparation [101], much higher than the current study findings. This dissimilarity may be due to the large sample size $(n=1680)$ and large age group distribution ( 3 to 45 years). The geographic area may also be a factor for this difference.

In wet mount film, the current study showed that ova of Ascaris lumbricoides $3(1.4 \%)$, Trichuris trichiura $1(0.5 \%)$, and mixed infection 2 (0.9\%) were detected. A study reported $0.9 \%$ Trichuris trichiura, but no Ascaris lumbricoides were found on hospitalized pediatric diarrheic children ( $<5$ years), according to our study [88]. Another study demonstrated $0.6 \%$ of Trichuris trichiura ova, but Ascaris lumbricoides was 9\% [102]. Another study reported prevalence of Ascaris lumbricoides and Trichiuris trichura ova was $8.2 \%$ and $0.9 \%$, respectively [103]. In our research, the relatively low number of helminths was detected because of the urban setting of the study population, who probably had better sanitation and hygiene practices. Another cause could be the ingestion of anthelminthic drugs at a regular interval.

Age and sex-specific vulnerability are essential for the prevalence of diarrheal illness, where various factors can contribute to this. These may include biochemical factors like hormones, enzymes, specific proteins, genetic or immunologic factors, food habits, culture, etc. [104]. 
Cryptosporidium was found positive in $1.4 \%$ of diarrheic samples by modified Z-N staining. A surveillance study on children under 12 years old in Tehran was done where the prevalence rate of the protozoa was $1.19 \%$ [66]. Another survey on pediatric children ( $<5$ years) reported $2.3 \%$ Cryptosporidium oocyst [97]. A study reflected detection rate of Cryptosporidium spp. from the outdoor patients of ICDDR'B was 4.44\% [40]. In Malaysia, the prevalence of these protozoa among diarrheic subjects ( $<12$ years) was $4.62 \%$ by modified Ziehl-Neelsen (mZN) staining [105, 106]. In Cameroon, a hospital-based cross-sectional study among children aged $<5$ years reflects that the prevalence of Cryptosporidium infection was $13.4 \%$ in microscopy (mZN staining), having the highest detection rate at 3160 months' group [85], which is dissimilar to this study. Several factors may play a vital role in this higher prevalence of cryptosporidiosis, such as geographic region, seasonal variation, age, personal hygiene, drinking or using untreated water, no exclusive breastfeeding, low educational status, and poor socioeconomic status of the parents.

In this study, some pitfalls are responsible for the small number of trophozoite and/or cyst and oocyst detection. Direct microscopic examination after modified Z-N staining of Cryptosporidium relies on morphologic recognition of small-sized oocysts that may be scanty in number. Hence, that could not be easy to find out. Again, they could be inconsistently stained, and misdiagnosis may happen. Therefore, this method is impractical to standardize as it is influenced by the microscopist's individual skills of the microscopist involved ${ }^{42}$.

Moreover, the procedure is incapable of detecting the low parasite count. Collecting at least three stool samples on alternate days is often indicated because of intermittent shedding of protozoan cysts and oocysts. But it's difficult and inconvenient to go for three samples from the same patient. Though conventional microscopy of more than one fecal sample is still recommended to diagnose intestinal protozoa in the stool samples, its sensitivity is still low even after multiple examinations. Also, the parasite might be disguised by bile pigment and not visualized by wet mount examination [101]. But this study was done with a single fecal sample so that a low parasite concentration could be missed through microscopy. These could be the reason behind their relatively low rate of detection.

By nested PCR, Cryptosporidium spp. was found positive in $4.1 \%$ samples. A study was shown, where the prevalence of Cryptosporidium was $4.8 \%$ among children below five years of age with diarrhea [107]. A longitudinal cohort study was done on Bangladeshi slum children where the same procedure found Cryptosporidium positive cases in $6.3 \%$ cases [40]. A prospective study on children under 16 years showed that $7.7 \%$ of patients were detected by PCR [60]. Another study found the prevalence of this parasite is about $1.3 \%$ [108]. Improved sanitation, safe drinking water, awareness about health, and hygiene enable lower prevalence of these parasitic diseases in the community [109]. Another cause may lie in examining a single fecal specimen per individual for diagnosis, which is less sensitive than the use of multiple samples $[44,56]$. 
Moreover, the study was performed in urban settings rather than rural or slum areas. PCR is considered a more sensitive and specific diagnostic method, but some limitations remain. There is a list of PCR inhibitors in stool samples, namely lipids, hemoglobin, bilirubin, bile salts, polysaccharides from mucous, bacteria, and food degradation products which can also affect the result of amplification. To minimize the effect of DNA inhibitors, commercial kits, including extraction columns, have been used to purify the DNA. Despite using such a kit, false-negative results may happen $[110,111]$.

The highest cases of Cryptosporidium were detected in the same age group ( 1 to 5 years) $7 / 103(6.79 \%)$ followed by <1-year age group $2 / 66$ (3.03\%), which was not statistically significant according to $p$ value $(p=0.376)$. Moreover, we revealed from our study that all Cryptosporidium positive cases were $<3$ years old children. It was shown in a study that the highest prevalence of Cryptosporidium infection was found in 3-4 years (14.3\%) followed by $<1$-year age group (4.5\%) [107]. A study found that Cryptosporidium infection was predominant among children $<5$ years (22\%) [49]. The majority of the infected cases were children $<4$ years of age [107]. Children at this age ( 1 to 5 years) develop a habit of putting unwashed hands, toys, and other objects inside their mouths.

Moreover, their compromised immunological status and poor hygiene practices lead them susceptible to intestinal infections, especially at this period $[112,113]$. The infection rate decreased in higher age groups with minimum infection rate because of the improved immunological status of the individual $[39,114]$. It is observed that there is a difference in detection rate with other studies. One reason could be that it was a tertiary hospital-based study rather than a rural or slum-based one. On the other side, our study's low detection rate may suggest an improved living standard of the study participants. It may be due to the improvement of the sanitation and hygiene system. Empirical use of antiparasitic drugs could be one of the reasons behind the low prevalence of intestinal parasites in our country $[115,116]$. Failure to detect intestinal protozoan parasites may be due to seasonal variation and the intermittent nature of excretion of this parasite in the stool $[47,117]$.

In this study, male predominance was observed in the case of Cryptosporidium Spp. Infection was similar to Hawash et al. [118], but the opposite picture was found by another study where females $[119,120]$ were affected more. This discrimination is unclear because under-five children of both sexes are engaged in the same recreational activity and are likely to be exposed to the same environmental conditions but could probably be because the males constitute the majority of the study population.

Regarding this study, the association of microscopic findings with PCR for pathogens showed high statistical significance $(p<0.001)$. The sensitivity of Cryptosporidium microscopy was $33.3 \%$, and specificity was $100 \%$ in the present study. Two other studies found similar validity $[121,122]$. 
Globally, foodborne cryptosporidiosis has been accounted for the significant reason for such infestation [123-125]. Additionally, drinking water from swimming pools, waterparks, fountains, lakes, and rivers contaminated with Cryptosporidium remains one of the common causes of spreading cryptosporidiosis [126-128]. This water source could be contaminated by fecal matter. In some city areas, sewage and toilet wastage may get into the surface water, which could be a potential concern for the fecal-oral transmission of this protozoan parasite. Furthermore, cryptosporidiosis has been positioned $5^{\text {th }}$ among the 24 most significant foodborne parasites [129, 130]. The World Bank reported that $98 \%$ of Bangladeshi people currently have access to better-quality water. However, water quality remains poor across the country because $80 \%$ possess microbial contamination [131]. UNICEF/WHO reported that about $25 \%$ of the Bangladeshi population does not have safe drinking water resources in their homes [132]. The results of risk factor analysis support the role of having unsafe drinking water in Cryptosporidium infection that is statistically significant ( $p$-value=0.043), which agrees with another study conducted in Pakistan [133]. Another critical issue is that Cryptosporidium oocysts are highly resistant to numerous disinfectant agents [133-135] and are killed by boiling water above $70{ }^{\circ} \mathrm{C}$ less than 1 minute [136]. In addition, multiple studies, including the WHO guidelines for drinking water quality, also suggest that those oocysts become non-viable and inactivated at $60-71.7^{\circ} \mathrm{C}[119,125$, $133,138]$.

Another salient factor behind protozoal diarrhea is inadequate hygiene practices like handwashing [139-141]. Our study found a significant association between poor hand washing practice and cryptosporidiosis ( $p$ value $=0.001$ ). It may be due to improper washing of hands during the handling of infant feeding bottles. Moreover, there is a tradition of practicing force-feeding techniques with bare hands to ensure enough food intake by the children to support their growth $[142,143]$. The hazard of bare hands (not properly washed) enables direct transmission of this foodborne protozoan disease [144, 145]. These malpractices welcome chances to ingest food and water contaminated with oocysts described above and are shed from infected individuals [146, 147].

Undoubtedly, breastfeeding has a widespread impact on children's health conditions, and there remains a significant correlation between breastfeeding and diarrhea [148-150]. Our study speculated that failure of exclusive breastfeeding was associated with Cryptosporidium infection [120,151]. It can be explained that the mother's milk provides the bulk amount of antibodies, Immunoglobulin A ( $\lg A)$, which offers passive protective immunity against various parasitic infections $[120,151,152]$. Multiple studies reported that parasitic-infested infection is almost imprisoned till 6 months of infant and when complementary foods are associated with infective diarrhea [107, 153, 154].

Though contact with animals has been reported as a risk factor for this infection [155-157] nevertheless, we observed a higher distribution of this pathogen in children without animal rearing. Our findings were similar to earlier studies $[43,158]$. The finding suggests the $20 \mid \mathrm{P}$ a g e 
transmission mode could be person-to-person contact-no association of the pathogen with the rural resident, supporting some previous studies [108, 114, 159, 160].

\section{Conclusion}

Therefore, it can be concluded that the PCR method demonstrated better results than the traditional microscopic method as it yields more positive results. Using this procedure, we can adequately diagnose the parasitic causes of diarrhea among the children, bringing considerable advantages in their treatment. As a result, irrational use of antibiotics will be reduced, and the rate of antibiotic resistance will be minimized. Moreover, it can be used for research purposes to detect protozoan parasites like Cryptosporidium. This study gives an idea about the prevalence of protozoan causes of diarrhea in this locality or region.

\section{Recommendation}

The samples were identified positively by mZN staining for Cryptosporidium spp.; oocyst was successfully proved positive by molecular assay (PCR), which recommends the practice of PCR approaches and conventional microscopic procedures to overthrow the practice the diagnostic drawbacks. So, the staining method should be established in combination with wet mount preparation as routine examination for stool to detect and diagnose the parasite effectively. Moreover, molecular analysis is also recommended where facilities are available. This would help us precisely diagnose the protozoa. Further molecular analysis like DNA sequencing can be done, which will provide us with specific information about the species and genotypes, hence lending the researcher a transparent idea about the epidemiology to identify risk factors, mode of transmission, pathogenicity, genetic diversity, etc.

\section{Key Messages}

- Parasites are one of the critical causes of pediatric diarrheic disease in our community.

- mZN staining should be introduced in routine-based detection of Cryptosporidium spp.

- The practice of regular hand washing and consumption of boiled water is an essential factor in minimizing parasitic infection, including cryptosporidiosis.

Consent for Publication: The author reviewed and approved the final version and has agreed to be accountable for all aspects of the work, including any accuracy or integrity issues.

Disclosure: The author declares that they do not have any financial involvement or affiliations with any organization, association, or entity directly or indirectly with the subject matter or materials presented in this article. This includes honoraria, expert testimony, 
employment, ownership of stocks or options, patents or grants received or pending, or royalties.

Funding: This paper was not funded.

Acknowledgments: The authors show gratitude to Naufela Nafisa Ahmad, Master of Arts in English Language (Linguistics), Jalan Wangsa Delima 7, Wangsa Maju, 53300 Kuala Lumpur, Malaysia, for revising and providing her expert opinion about the quality of the English language of this article. The authors also express gratitude to Faiza Binte Mozammel, Photographer and Editor, 7/16/1 South Mugdapara Dhaka, Bangladesh, for her kind effort and time regarding image development and editing.

Authorship Contribution: All authors made a significant contribution to the work reported, whether that is in the conception, study design, execution, acquisition of data, analysis, and interpretation, or in all these areas; took part in drafting, revising, or critically reviewing the article; gave final approval of the version to be published; have agreed on the journal to which the article has been submitted, and have decided to be accountable for all aspects of the work.

Data Availability: The current study data is only available from the principal author for research purposes.

\section{References}

1. Sweetser S. Evaluating the patient with diarrhea: a case-based approach. Mayo Clin Proc. 2012;87(6):596-602. doi: 10.1016/j.mayocp.2012.02.015.

2. Corinaldesi R, Stanghellini V, Barbara G, Tomassetti P, De Giorgio R. Clinical approach to diarrhea. Intern Emerg Med. 2012;7 (Suppl 3): S255-62. doi: 10.1007/s11739-012-0827-4.

3. Nemeth V, Pfleghaar N. Diarrhea. [Updated 2021 Nov 29]. In: StatPearls [Internet]. Treasure Island (FL): StatPearls Publishing; 2022 Jan-. Available from: https://www.ncbi.nlm.nih.gov/books/NBK448082/ [Accessed February 17, 2022]

4. Barr W, Smith A. Acute diarrhea. Am Fam Physician. 2014;89(3):180-9.

5. DuPont HL. Persistent Diarrhea: A Clinical Review. JAMA. 2016 June 28;315(24):2712-23. doi: 10.1001/jama.2016.7833.

6. Sur D, Ramamurthy T, Deen J, Bhattacharya SK. Shigellosis: challenges \& management issues. Indian J Med Res. 2004;120(5):454-62.

7. Rabbani GH, Ahmed S, Hossain I, Islam R, Marni F, Akhtar M, Majid N. Green banana reduces clinical severity of childhood shigellosis: a double-blind, randomized, controlled clinical trial. Pediatr Infect Dis J. 2009;28(5):420-5. doi: 10.1097/INF.0b013e31819510b5.

8. Varre JV. Vaccines are not one size fits all, just like medications: rotavirus vaccine study. Clin Exp Vaccine Res. 2021;10(2):148-150. doi: 10.7774/cevr.2021.10.2.148. $\mathrm{s}$ 
9. Gould CV, File TM Jr, McDonald LC. Causes, Burden, and Prevention of Clostridium difficile Infection. Infect Dis Clin Pract (Baltim Md). 2015;23(6):281-288. doi: 10.1097/IPC.0000000000000331.

10. Liu J, Platts-Mills JA, Juma J, Kabir F, Nkeze J, Okoi C, Operario DJ, Uddin J, Ahmed $\mathrm{S}$, Alonso $\mathrm{PL}$, Antonio $\mathrm{M}$, Becker SM, Blackwelder WC, Breiman RF, Faruque AS, Fields B, Gratz J, Haque R, Hossain A, Hossain MJ, Jarju S, Qamar F, lqbal NT, Kwambana $B$, Mandomando I, McMurry TL, Ochieng C, Ochieng JB, Ochieng $M$, Onyango C, Panchalingam S, Kalam A, Aziz F, Qureshi S, Ramamurthy T, Roberts JH, Saha D, Sow SO, Stroup SE, Sur D, Tamboura B, Taniuchi M, Tennant SM, Toema D, Wu Y, Zaidi A, Nataro JP, Kotloff KL, Levine MM, Houpt ER. Use of quantitative molecular diagnostic methods to identify causes of diarrhea in children: a reanalysis of the GEMS case-control study. Lancet. 2016;388(10051):1291-301. doi: 10.1016/S0140-6736(16)31529-X.

11. Bergman $H$, Henschke $N$, Hungerford D, Pitan F, Ndwandwe D, Cunliffe N, SoaresWeiser K. Vaccines for preventing rotavirus diarrhea: vaccines in use. Cochrane Database Syst Rev. 2021;11(11): CD008521. doi: 10.1002/14651858.CD008521.

12. World Health Organization. Diarrhoeal disease. Key Facts. Available at https://www.who.int/news-room/fact-sheets/detail/diarrhoeal-disease [Accessed February 17, 2022]

13. Ugboko HU, Nwinyi OC, Oranusi SU, Oyewale JO. Childhood diarrhoeal diseases in developing countries. Heliyon. 2020;6(4): e03690. doi: 10.1016/j.heliyon. 2020.e03690

14. Boschi-Pinto C, Velebit L, Shibuya K. Estimating child mortality due to diarrhea in developing countries. Bull World Health Organ. 2008 Sep;86(9):710-7. doi: 10.2471/blt.07.050054.

15. World Health Organization. Children: improving survival and well-being. 2020. Available at https://www.who.int/news-room/fact-sheets/detail/childrenreducing-mortality [Accessed February 17, 2022]

16. Demissie GD, Yeshaw Y, Aleminew W, Akalu Y. Diarrhea and associated factors among under-five children in sub-Saharan Africa: Evidence from demographic and health surveys of 34 sub-Saharan countries. PLoS One. 2021;16(9): e0257522. doi: 10.1371/journal.pone.0257522.

17. Pinkerton R, Oriá RB, Lima AA, Rogawski ET, Oriá MO, Patrick PD, Moore SR, Wiseman BL, Niehaus MD, Guerrant RL. Early Childhood Diarrhea Predicts Cognitive Delays in Later Childhood Independently of Malnutrition. Am J Trop Med Hyg. 2016;95(5):1004-1010. doi: 10.4269/ajtmh.16-0150.

18. Khalil IA, Troeger C, Rao PC, Blacker BF, Brown A, Brewer TG, Colombara DV, De Hostos EL, Engmann C, Guerrant RL, Haque R, Houpt ER, Kang G, Korpe PS, Kotloff KL, Lima AAM, Petri WA Jr, Platts-Mills JA, Shoultz DA, Forouzanfar MH, Hay SI, Reiner RC Jr, Mokdad AH. Morbidity, mortality, and long-term consequences associated with diarrhea from Cryptosporidium infection in children younger than 5 years: a meta-analyses study. Lancet Glob Health. 2018; 6(7): e758-e768. doi: 10.1016/S2214-109X(18)30283-3. 
19. Troeger C, Colombara DV, Rao PC, Khalil IA, Brown A, Brewer TG, Guerrant RL, Houpt ER, Kotloff KL, Misra K, Petri WA Jr, Platts-Mills J, Riddle MS, Swartz SJ, Forouzanfar MH, Reiner RC Jr, Hay SI, Mokdad AH. Global disability-adjusted lifeyear estimates of long-term health burden and undernutrition attributable to diarrhoeal diseases in children younger than 5 years. Lancet Glob Health. 2018; 6(3): e255-e269. doi: 10.1016/S2214-109X(18)30045-7.

20. Fagundes-Neto U. Persistent diarrhea: still a serious public health problem in developing countries. Curr Gastroenterol Rep. 2013;15(9):345. doi: 10.1007/s11894-013-0345-1.

21. Melese B, Paulos W, Astawesegn FH, Gelgelu TB. Prevalence of diarrheal diseases and associated factors among under-five children in Dale District, Sidama zone, Southern Ethiopia: a cross-sectional study. BMC Public Health. 2019;19(1):1235. doi: 10.1186/s12889-019-7579-2.

22. Mokomane M, Kasvosve I, de Melo E, Pernica JM, Goldfarb DM. The global problem of childhood diarrhoeal diseases: emerging strategies in prevention and management. Ther Adv Infect Dis. 2018;5(1):29-43. doi:10.1177/2049936117744429

23. Kotloff KL. The Burden and Etiology of Diarrheal Illness in Developing Countries. Pediatr Clin North Am. 2017;64(4):799-814. doi: 10.1016/j.pcl.2017.03.006.

24. Chakravarty I, Bhattacharya A, Das SK. Water, sanitation, and hygiene: The unfinished agenda in the World Health Organization South-East Asia Region. WHO South East Asia J Public Health. 2017;6(2):22-33. doi: 10.4103/2224-3151.213787.

25. Squire SA, Ryan U. Cryptosporidium and Giardia in Africa: current and future challenges. Parasit Vectors. 2017;10(1):195. doi: 10.1186/s13071-017-2111-y.

26. Piechulek H, Al-Sabbir A, Mendoza-Aldana J. Diarrhea and ARI in rural areas of Bangladesh. Southeast Asian J Trop Med Public Health. 2003;34(2):337-42.

27. Hasan MZ, Mehdi GG, De Broucker G, Ahmed S, Ali MW, Martin Del Campo J, Constenla D, Patenaude B, Uddin MJ. The economic burden of diarrhea in children under 5 years in Bangladesh. Int J Infect Dis. 2021; 107: 37-46. doi: 10.1016/j.ijid.2021.04.038.

28. Ahmed S, Dorin F, Satter SM, Sarker AR, Sultana M, Gastanaduy PA, Parashar U, Tate JE, Heffelfinger JD, Gurley ES, Khan JAM. The economic burden of rotavirus hospitalization among children $<5$ years of age in selected hospitals in Bangladesh. Vaccine. 2021;39(48):7082-7090. doi: 10.1016/j.vaccine.2021.10.003.

29. Nguyen TV, Le Van P, Le Huy C, Weintraub A. Diarrhea caused by rotavirus in children less than 5 years of age in Hanoi, Vietnam. J Clin Microbiol. 2004;42(12):5745-5750. doi:10.1128/JCM.42.12.5745-5750.2004

30. LeClair CE, McConnell KA. Rotavirus. [Updated 2022 January 7]. In: StatPearls [Internet]. Treasure Island (FL): StatPearls Publishing; 2022 Jan-. Available from: https://www.ncbi.nlm.nih.gov/books/NBK558951/ [Accessed on February 18, 2022] 
31. Tian L, Zhu X, Chen Z, Liu W, Li S, Yu W, Zhang W, Xiang X, Sun Z. Characteristics of bacterial pathogens associated with acute diarrhea in children under 5 years of age: a hospital-based cross-sectional study. BMC Infect Dis. 2016; 16:253. doi: 10.1186/s12879-016-1603-2.

32. Zhou Y, Zhu X, Hou H, Lu Y, Yu J, Mao L, Mao L, Sun Z. Characteristics of diarrheagenic Escherichia coli among children under 5 years of age with acute diarrhea: a hospital-based study. BMC Infect Dis. 2018;18(1):63. doi: 10.1186/s12879-017-2936-1.

33. Adam MA, Wang J, Enan KA, Shen $H$, Wang $H$, El Hussein AR, Musa AB, Khidir IM, Ma X. Molecular Survey of Viral and Bacterial Causes of Childhood Diarrhea in Khartoum State, Sudan. Front Microbiol. 2018; 9:112. doi: 10.3389/fmicb.2018.00112.

34. Zhu XH, Tian L, Cheng ZJ, Liu WY, Li S, Yu WT, Zhang WQ, Xiang X, Sun ZY. Viral and Bacterial Etiology of Acute Diarrhea among Children under 5 Years of Age in Wuhan, China. Chin Med J (Engl). 2016;129(16):1939-44. doi: 10.4103/03666999.187852.

35. Wang X, Wang J, Sun $H$, Xia S, Duan R, Liang J, Xiao Y, Qiu H, Shan G, Jing H. Etiology of Childhood Infectious Diarrhea in a Developed Region of China: Compared to Childhood Diarrhea in a Developing Region and Adult Diarrhea in a Developed Region. PLoS One. 2015;10(11):e0142136. doi: 10.1371/journal.pone.0142136.

36. Boughattas S, Behnke JM, Al-Ansari K, Sharma A, Abu-Alainin W, Al-Thani A, AbuMadi MA. Molecular Analysis of the Enteric Protozoa Associated with Acute Diarrhea in Hospitalized Children. Front Cell Infect Microbiol. 2017;7:343. doi: 10.3389/fcimb.2017.00343.

37. Osman M, El Safadi D, Cian A, Benamrouz S, Nourrisson C, Poirier P, Pereira B, Razakandrainibe R, Pinon A, Lambert C, Wawrzyniak I, Dabboussi F, Delbac F, Favennec L, Hamze M, Viscogliosi E, Certad G. Prevalence and Risk Factors for Intestinal Protozoan Infections with Cryptosporidium, Giardia, Blastocystis and Dientamoeba among Schoolchildren in Tripoli, Lebanon. PLoS Negl Trop Dis. 2016;10(3): e0004496. doi: 10.1371/journal.pntd.0004496.

38. Ryan U, Zahedi A, Paparini A. Cryptosporidium in humans and animals-a one health approach to prophylaxis. Parasite Immunol. 2016;38(9):535-47. doi: 10.1111/pim.12350.

39. Bouzid M, Hunter PR, Chalmers RM, Tyler KM. Cryptosporidium pathogenicity and virulence. Clin Microbiol Rev. 2013;26(1):115-34. doi: 10.1128/CMR.00076-12.

40. Korpe PS, Haque R, Gilchrist C, Valencia C, Niu F, Lu M, Ma JZ, Petri SE, Reichman D, Kabir M, Duggal P, Petri WA Jr. Natural History of Cryptosporidiosis in a Longitudinal Study of Slum-Dwelling Bangladeshi Children: Association with Severe Malnutrition. PLoS Negl Trop Dis. 2016;10(5): e0004564. doi: 10.1371/journal.pntd.0004564.

41. Shirley DA, Moonah SN, Kotloff KL. Burden of disease from cryptosporidiosis. Curr Opin Infect Dis. 2012;25(5):555-63. doi: 10.1097/QCO.0b013e328357e569. 
42. Baptista RP, Cooper GW, Kissinger JC. Challenges for Cryptosporidium Population Studies. Genes. 2021 Jun;12(6):894. DOI: 10.3390/genes12060894.

43. Krumkamp R, Aldrich C, Maiga-Ascofare O, Mbwana J, Rakotozandrindrainy N, Borrmann S, Caccio SM, Rakotozandrindrainy R, Adegnika AA, Lusingu JP, Amuasi J. Transmission of Cryptosporidium Species Among Human and Animal Local Contact Networks in Sub-Saharan Africa: A Multicountry Study. Clinical Infectious Diseases. 2021;72(8):1358-66. doi: 10.1093/cid/ciaa223.

44. O'Leary JK, Sleator RD, Lucey B. Cryptosporidium spp. diagnosis and research in the 21st century. Food and Waterborne Parasitology. 2021;24: e00131. doi: 10.1016/j.fawpar. 2021.e00131

45. Firoozi Z, Sazmand A, Zahedi A, Astani A, Fattahi-Bafghi A, Kiani-Salmi N, Ebrahimi B, Dehghani-Tafti A, Ryan U, Akrami-Mohajeri F. Prevalence and genotyping identification of Cryptosporidium in adult ruminants in central Iran. Parasites \& vectors. 2019;12(1):1-6. doi: 10.1186/s13071-019-3759-2.

46. Dabas A, Shah D, Bhatnagar S, Lodha R. Epidemiology of Cryptosporidium in Pediatric Diarrheal Illnesses. Indian Pediatr. 2017;54(4):299-309. doi: 10.1007/s13312-017-1093-3.

47. Leitch GJ, He Q. Cryptosporidiosis-an overview. J Biomed Res. 2012; 25(1):1-16.

48. Di Genova BM, Tonelli RR. Infection Strategies of Intestinal Parasite Pathogens and Host Cell Responses. Front Microbiol. 2016; 7:256. doi: 10.3389/fmicb.2016.00256. PMID: 26973630; PMCID: PMC4776161.

49. Semrad CE. Approach to the Patient with Diarrhea and Malabsorption. Goldman's Cecil Medicine. 2012;895-913. doi:10.1016/B978-1-4377-1604-7.00142-1

50. Woods TA. Diarrhea. In: Walker HK, Hall WD, Hurst JW, editors. Clinical Methods: The History, Physical, and Laboratory Examinations. 3rd edition. Boston: Butterworths; $\quad$ 1990. Chapter $88 . \quad$ Available from: https://www.ncbi.nIm.nih.gov/books/NBK414/ [Accessed February 18, 2022]

51. Hodges K, Gill R. Infectious diarrhea: Cellular and molecular mechanisms. Gut Microbes. 2010;1(1):4-21. doi: 10.4161/gmic.1.1.11036.

52. Thiagarajah JR, Donowitz M, Verkman AS. Secretory diarrhea: mechanisms and emerging therapies. Nat Rev Gastroenterol Hepatol. 2015;12(8):446-57. doi: 10.1038/nrgastro.2015.111.

53. Kirkpatrick BD, Noel F, Rouzier PD, Powell JL, Pape JW, Bois G, Alston WK, Larsson CJ, Tenney K, Ventrone C, Powden C, Sreenivasan M, Sears CL. Childhood cryptosporidiosis is associated with a persistent systemic inflammatory response. Clin Infect Dis. 2006;43(5):604-8. doi: 10.1086/506565.

54. Kiela PR, Ghishan FK. Physiology of Intestinal Absorption and Secretion. Best Pract Res Clin Gastroenterol. 2016;30(2):145-59. doi: 10.1016/j.bpg.2016.02.007.

55. Checkley W, White Jr AC, Jaganath D, Arrowood MJ, Chalmers RM, Chen XM, Fayer R, Griffiths JK, Guerrant RL, Hedstrom L, Huston CD. A review of the global burden, novel diagnostics, therapeutics, and vaccine targets for Cryptosporidium. 
The Lancet Infectious Diseases. 2015 January 1;15(1):85-94. doi: 10.1016/S14733099(14)70772-8.

56. Khurana S, Chaudhary P. Laboratory diagnosis of cryptosporidiosis. Tropical parasitology. 2018 Jan;8(1):2. doi: 10.4103/tp.TP_34_17

57. Collinet-Adler S, Ward HD. Cryptosporidiosis: environmental, therapeutic, and preventive challenges. Eur J Clin Microbiol Infect Dis. 2010;29(8):927-35. doi: 10.1007/s10096-010-0960-9.

58. Sharma P, Khurana S, Sharma A, Sehgal R, Malla N. Presence of intracellular viruses in human Cryptosporidium isolates. Ann Parasitol. 2016;62(2):139-47. doi: 10.17420/ap6202.46.

59. Desai NT, Sarkar R, Kang G. Cryptosporidiosis: An under-recognized public health problem. Trop Parasitol. 2012;2(2):91-8. doi: 10.4103/2229-5070.105173.

60. Moore CE, Elwin K, Phot N, Seng C, Mao S, Suy K, Kumar V, Nader J, Bousfield R, Perera S, Bailey JW, Beeching NJ, Day NP, Parry CM, Chalmers RM. Molecular Characterization of Cryptosporidium Species and Giardia duodenalis from Symptomatic Cambodian Children. PLoS NegI Trop Dis. 2016;10(7):e0004822. doi: 10.1371/journal.pntd.0004822.

61. Luby SP, Rahman M, Arnold BF, Unicomb L, Ashraf S, Winch PJ, Stewart CP, Begum F, Hussain F, Benjamin-Chung J, Leontsini E. Effects of water quality, sanitation, handwashing, and nutritional interventions on diarrhea and child growth in rural Bangladesh: a cluster randomized controlled trial. The Lancet Global Health. 2018;6(3): e302-15. doi:10.1016/S2214-109X (17)30490-4

62. Lin A, Ercumen A, Benjamin-Chung J, Arnold BF, Das S, Haque R, Ashraf S, Parvez $\mathrm{SM}$, Unicomb L, Rahman M, Hubbard AE. A cluster-randomized controlled trial, the effects of water, sanitation, handwashing, and nutritional interventions on child enteric protozoan infections in rural Bangladesh. Clinical Infectious Diseases. 2018 Oct 30;67(10):1515-22. doi: 10.1021/acs.est.8b05153

63. Sow SO, Muhsen K, Nasrin D, Blackwelder WC, Wu Y, Farag TH, Panchalingam $S$, Sur D, Zaidi AK, Faruque AS, Saha D, Adegbola R, Alonso PL, Breiman RF, Bassat $Q$, Tamboura B, Sanogo D, Onwuchekwa U, Manna B, Ramamurthy T, Kanungo S, Ahmed S, Qureshi S, Quadri F, Hossain A, Das SK, Antonio M, Hossain MJ, Mandomando I, Nhampossa T, Acácio S, Omore R, Oundo JO, Ochieng JB, Mintz ED, O'Reilly CE, Berkeley LY, Livio S, Tennant SM, Sommerfelt H, Nataro JP, ZivBaran T, Robins-Browne RM, Mishcherkin V, Zhang J, Liu J, Houpt ER, Kotloff KL, Levine MM. The Burden of Cryptosporidium Diarrheal Disease among Children < 24 Months of Age in Moderate/High Mortality Regions of Sub-Saharan Africa and South Asia, Utilizing Data from the Global Enteric Multicenter Study (GEMS). PLoS Negl Trop Dis. 2016;10(5): e0004729. doi: 10.1371/journal.pntd. 0004729..

64. Dabas A, Shah D, Bhatnagar S, Lodha R. Epidemiology of Cryptosporidium in pediatric diarrheal illnesses. Indian pediatrics. 2017 Apr;54(4):299-309. doi: 10.1007/s13312-017-1093-3. 
65. Areeshi MY, Beeching NJ, Hart CA. Cryptosporidiosis in Saudi Arabia and neighboring countries. Ann Saudi Med. 2007;27(5):325-332. doi:10.5144/02564947.2007.325

66. Tahvildar-Biderouni F, Salehi N. Detection of Cryptosporidium infection by modified ziehl-Nielsen and PCR methods in children with diarrheal samples in pediatric hospitals in Tehran. Gastroenterol Hepatol Bed Bench. 2014;7(2):125-30.

67. Kalantari N, Ghaffari S, Bayani M. Cryptosporidium spp. Infection in Iranian children and immunosuppressive patients: A systematic review and meta-analysis. Caspian J Intern Med. 2018;9(2):106-115. doi:10.22088/cjim.9.2.106

68. Casemore DP, Armstrong M, Sands RL. Laboratory diagnosis of cryptosporidiosis. J Clin Pathol. 1985 Dec;38(12):1337-41. doi: 10.1136/jcp.38.12.1337.

69. Chalmers RM, Atchison C, Barlow K, Young Y, Roche A, Manuel R. An audit of the laboratory diagnosis of cryptosporidiosis in England and Wales. J Med Microbiol. 2015;64(7):688-693. doi: 10.1099/jmm.0.000089.

70. Rusnak J, Hadfield TL, Rhodes MM, Gaines JK. Detection of Cryptosporidium oocysts in human fecal specimens by an indirect immunofluorescence assay with monoclonal antibodies. J Clin Microbiol. 1989;27(5):1135-6. doi: 10.1128/jcm.27.5.1135-1136.1989.

71. Ghoshal U, Jain V, Dey A, Ranjan P. Evaluation of enzyme-linked immunosorbent assay for stool antigen detection for the diagnosis of cryptosporidiosis among HIV negative immunocompromised patients in a tertiary care hospital of northern India. J Infect Public Health. 2018;11(1):115-119. doi: 10.1016/j.jiph.2017.06.007.

72. Chalmers RM, Campbell BM, Crouch N, Charlett A, Davies AP. Comparison of diagnostic sensitivity and specificity of seven Cryptosporidium assays used in the UK. J Med Microbiol. 2011;60(Pt 11):1598-1604. doi: 10.1099/jmm.0.034181-0.

73. Robinson G, Chalmers RM. Cryptosporidium Diagnostic Assays: Microscopy. Methods Mol Biol. 2020; 2052:1-10. doi: 10.1007/978-1-4939-9748-0_1.

74. Morgan UM, Pallant L, Dwyer BW, Forbes DA, Rich G, Thompson RC. Comparison of PCR and microscopy for detection of Cryptosporidium parvum in human fecal specimens: clinical trial. J Clin Microbiol. 1998;36(4):995-8. doi: 10.1128/JCM.36.4.995-998.1998.

75. Cunha FS, Peralta RHS, Peralta JM. New insights into the detection and molecular characterization of Cryptosporidium with emphasis in Brazilian studies: a review. Rev Inst Med Trop Sao Paulo. 2019;61: e28. doi: 10.1590/S1678-9946201961028.

76. Xiao L. Overview of Cryptosporidium presentations at the 10th International Workshops on Opportunistic Protists. Eukaryot Cell. 2009;8(4):429-36. doi: 10.1128/EC.00295-08.

77. Khan A, Shaik JS, Grigg ME. Genomics and molecular epidemiology of Cryptosporidium species. Acta Trop. 2018; 184: 1-14. doi: 10.1016/j.actatropica.2017.10.023.

78. Nazemalhosseini Mojarad E, Keshavarz A, Taghipour N, Haghighi A, Kazemi B, Athari A. Genotyping of Cryptosporidium spp. in clinical samples: PCR-RFLP 
analysis of the TRAP-C2 gene. Gastroenterol Hepatol Bed Bench. 2011 Winter;4(1):29-33. PMID: 24834152; PMCID: PMC4017402.

79. Cunha FS, Peralta RHS, Peralta JM. New insights into the detection and molecular characterization of Cryptosporidium with emphasis in Brazilian studies: a review. Rev Inst Med Trop Sao Paulo. 2019;61:e28. doi: 10.1590/S1678-9946201961028.

80. Jex AR, Smith HV, Monis PT, Campbell BE, Gasser RB. Cryptosporidium-biotechnological advances in the detection, diagnosis, and analysis of genetic variation. Biotechnol Adv. 2008;26(4):304-17. doi: 10.1016/j.biotechadv.2008.02.003.

81. Gilchrist CA, Cotton JA, Burkey C, Arju T, Gilmartin A, Lin Y, Ahmed E, Steiner K, Alam M, Ahmed S, Robinson G, Zaman SU, Kabir M, Sanders M, Chalmers RM, Ahmed T, Ma JZ, Haque R, Faruque ASG, Berriman M, Petri WA. Genetic Diversity of Cryptosporidium hominis in a Bangladeshi Community as Revealed by WholeGenome Sequencing. J Infect Dis. 2018 June 20;218(2):259-264. doi: 10.1093/infdis/jiy121. PMID: 29514308; PMCID: PMC6009673.

82. Steiner KL, Ahmed S, Gilchrist CA, Burkey C, Cook H, Ma JZ, Korpe PS, Ahmed E, Alam M, Kabir M, Tofail F, Ahmed T, Haque R, Petri WA Jr, Faruque ASG. Species of Cryptosporidia Causing Subclinical Infection Associated with Growth Faltering in Rural and Urban Bangladesh: A Birth Cohort Study. Clin Infect Dis. 2018 October 15;67(9):1347-1355. doi: 10.1093/cid/ciy310. PMID: 29897482; PMCID: PMC6186860.

83. Hira KG, Mackay MR, Hempstead AD, Ahmed S, Karim MM, O'Connor RM, Hibberd PL, Calderwood SB, Ryan ET, Khan WA, Ward HD. Genetic diversity of Cryptosporidium spp. from Bangladeshi children. J Clin Microbiol. 2011 Jun;49(6):2307-10. doi: 10.1128/JCM.00164-11.

84. Ahmed T, Khanum H, Uddin MS, Barua P, Arju T, Kabir M, Haque R. Entamoeba histolytica, Giardia lamblia, and Cryptosporidium spp. Infection in children in an urban slum area of Bangladesh. Biores Commun. 2016; 2(1): 175-181. doi:10.5216/rpt.v48i2.58571

85. Tombang AN, Ambe NF, Bobga TP, Nkfusai CN, Collins NM, Ngwa SB, Diengou NH, Cumber SN. Prevalence and risk factors associated with cryptosporidiosis among children within the ages 0-5 years attending the Limbe regional hospital, southwest region, Cameroon. BMC Public Health. 2019;19(1):1144. doi: 10.1186/s12889-019-7484-8.

86. Centers for Disease Control and Prevention (CDC) (2016). DPDx- Laboratory Identification of Parasites of Public Health Concern: Stool Specimens - Extraction of parasite DNA from fecal specimens using FastDNA kit [Online]. Available from: https://www.cdc.gov/dpdx/diagnosticprocedures/stool/dnaextraction.html [Accessed 20 August 2019].

87. Casemore DP. ACP Broadsheet 128: June 1991. Laboratory methods for diagnosing cryptosporidiosis. J Clin Pathol. 1991;44(6):445-451. doi:10.1136/jcp.44.6.445 
88. Koehler AV, Haydon SR, Jex AR, Gasser RB. Cryptosporidium and Giardia taxa in fecal samples from animals in catchments supplying the city of Melbourne with drinking water (2011 to 2015). Parasit Vectors. 2016;9(1):315. Published 2016 Jun 1. doi:10.1186/s13071-016-1607-1

89. Bauhofer AFL, Cossa-Moiane I, Marques S, et al. Intestinal protozoan infections among children 0-168 months with diarrhea in Mozambique: June 2014 - January 2018. PLoS Negl Trop Dis. 2020;14(4): e0008195. Published 2020 April 22. doi: 10.1371/journal.pntd.0008195

90. Coutinho BP, Oriá RB, Vieira CM, Sevilleja JE, Warren CA, Maciel JG, Thompson MR, Pinkerton RC, Lima AA, Guerrant RL. Cryptosporidium infection causes undernutrition and, conversely, weanling undernutrition intensifies infection. J Parasitol. 2008;94(6):1225-32. doi: 10.1645/GE1411.1.

91. Costa LB, JohnBull EA, Reeves JT, Sevilleja JE, Freire RS, Hoffman PS, Lima $A A$, Oriá RB, Roche JK, Guerrant RL, Warren CA. Cryptosporidiummalnutrition interactions: mucosal disruption, cytokines, and TLR signaling in a weaned murine model. J Parasitol. 2011;97(6):1113-20. doi: 10.1645/GE-2848.1.

92. Guerrant DI, Moore SR, Lima AA, Patrick PD, Schorling JB, Guerrant RL. Association of early childhood diarrhea and cryptosporidiosis with impaired physical fitness and cognitive function four seven years later in a poor urban community in northeast Brazil. Am J Trop Med Hyg. 1999;61(5):70713. doi: 10.4269/ajtmh.1999.61.707.

93. Aldeyarbi HM, Abu El-Ezz NM, Karanis P. Cryptosporidium and cryptosporidiosis: the African perspective. Environ Sci Pollut Res Int. 2016;23(14):13811-21. doi: 10.1007/s11356-016-6746-6.

94. Mahmoudi MR, Ongerth JE, Karanis P. Cryptosporidium and cryptosporidiosis: The Asian perspective. Int J Hyg Environ Health. 2017 Oct;220(7):1098-1109. doi: 10.1016/j.ijheh.2017.07.005.

95. Korpe PS, Valencia C, Haque R, Mahfuz M, McGrath M, Houpt E, Kosek M, McCormick BJJ, Penataro Yori P, Babji S, Kang G, Lang D, Gottlieb M, Samie A, Bessong P, Faruque ASG, Mduma E, Nshama R, Havt A, Lima IFN, Lima AAM, Bodhidatta L, Shreshtha A, Petri WA Jr, Ahmed T, Duggal P. Epidemiology and Risk Factors for Cryptosporidiosis in Children From 8 Lowincome Sites: Results From the MAL-ED Study. Clin Infect Dis. 2018;67(11):1660-1669. doi: 10.1093/cid/ciy355.

96. Pestechian N, Rasekh H, Rostami-Nejad M, Yousofi HA, Hosseini-Safa A. Molecular identification of Giardia lamblia; is there any correlation between diarrhea and genotyping in Iranian population? Gastroenterol Hepatol Bed Bench. 2014;7(3):168-72.

97. Pervin MK, Jhora ST, Paul S, Naher A, Sarkar D. Causative agents for diarrhea in under 5 children in a tertiary care hospital. Bang Med J Khulna. 2019; 51(1-2): 25-28. https://doi.org/10.3329/bmjk.v51i1-2.40470 
98. Hossain MR, Musa S, Zaman RF, Khanum H. Occurrence of intestinal parasites among school-going children of a slum area in Dhaka city. Bang J Zool. 2019; 47(1): 67-75. https://doi.org/10.3329/bjz.v47i1.42022

99. Chanu NO, Singh TS, Dutta S. Detection and genetic characterization of Giardia intestinalis in children with gastrointestinal symptoms by PCR RFLP in Sikkim, India. J Nat Sc Biol Med 2018;9:193-6. doi:10.4103/jnsbm.JNSBM_219_17

100. Abdullah I, Tak H, Ahmad F, Gul N. Prevalence and Associated Risk Factors for Giardiasis among Children in District Anantnag of Kashmir Valley, India. J Gastro Hepato Dis. 2016; 2(1): 106. http://dx.doi.org/10.19104/ighd.2016.106

101. Jahan N, Khatoon R, Ahmad S. A Comparison of Microscopy and EnzymeLinked Immunosorbent Assay for Diagnosis of Giardia lamblia in Human Faecal Specimens. J Clin Diagn Res. 2014;8(11): DC04-6. doi: 10.7860/JCDR/2014/9484.5087.

102. Roy E, Hasan KZ, Haque R, Haque AF, Siddique AK, Sack RB. Patterns and risk factors for helminthiasis in rural children aged under 2 in Bangladesh. South African Journal of Child Health. 2011; 5(3): 78-84.

103. Davlin SL, Jones AH, Tahmina S, Kawsar AA, Joshi A, Zaman SI, Rahman MM, Morawski BM, Deming MS, Imtiaz R, Karim MJ. Soil-transmitted helminthiasis in four districts in Bangladesh: household cluster surveys of prevalence and intervention status. BMC Public Health. 2020;20(1):672. doi: 10.1186/s12889-02008755-w.

104. Alam, S., Khanum, H., Zaman, R. F., \& Haque, R. (2013). Prevalence of Different Protozoan Parasites in Patients Visiting at ICDDR'B Hospital, Dhaka. Journal of the Asiatic Society of Bangladesh, Science, 39(1), 117-123. https://doi.org/10.3329/jasbs.v39i1.16040

105. Rossle NF, Latif B, Malik AS, Fadzli FM, Abu NA. Cryptosporidiosis among Children with Diarrhea Admitted to Hospital Selayang and Hospital, Sungai Buloh, Selangor, Malaysia. J Trop Med Parasitol. 2012;35:55-62.

106. Latif B, Rossle NF. Cryptosporidiosis among children with diarrhea in three Asian countries: A review. Asian Pacific Journal of Tropical Biomedicine. 2015; 5(11), 885-888. https://doi.org/10.1016/i.apjtb.2015.05.021

107. Anejo-Okopi JA, Okojokwu JO, Ebonyi AO, et al. Molecular characterization of Cryptosporidium in children aged 0- 5 years with diarrhea in Jos, Nigeria. Pan Afr Med J. 2016; 25:253 doi:10.11604/pamj.2016.25.253.10018

108. Kiani H, Haghighi A, Seyyedtabaei SJ, et al. Prevalence, Clinical Manifestations and Genotyping of Cryptosporidium Spp. in Patients with Gastrointestinal Illnesses in Western Iran. Iran J Parasitol. 2017;12(2):169-176.

109. Hutton G, Chase C. Water Supply, Sanitation, and Hygiene. In: Mock CN, Nugent $R$, Kobusingye $O$, et al., editors. Injury Prevention and Environmental Health. 3rd edition. Washington (DC): The International Bank for Reconstruction and Development / The World Bank; 2017 October 27. Chapter 9. Available from: 
https://www.ncbi.nlm.nih.gov/books/NBK525207/ doi: 10.1596/978-1-46480522-6_ch9 [Accessed February 19, 2022]

110. Anuar TS, Azreen SN, Salleh FM, Moktar N. Molecular epidemiology of giardiasis among Orang Asli in Malaysia: application of the triosephosphate isomerase gene. BMC Infect Dis. 2014 Feb 12; 14:78. doi: 10.1186/1471-2334-1478. PMID: 24520940; PMCID: PMC3933338.

111. Ahmed W, Simpson SL, Bertsch PM, Bibby K, Bivins A, Blackall LL, Bofill-Mas S, Bosch A, Brandão J, Choi PM, Ciesielski M, Donner E, D'Souza N, Farnleitner AH, Gerrity D, Gonzalez R, Griffith JF, Gyawali P, Haas CN, Hamilton KA, Hapuarachchi HC, Harwood VJ, Haque R, Jackson G, Khan SJ, Khan W, Kitajima M, Korajkic A, La Rosa G, Layton BA, Lipp E, McLellan SL, McMinn B, Medema G, Metcalfe S, Meijer WG, Mueller JF, Murphy $H$, Naughton CC, Noble RT, Payyappat S, Petterson S, Pitkänen T, Rajal VB, Reyneke B, Roman FA Jr, Rose JB, Rusiñol M, Sadowsky MJ, Sala-Comorera L, Setoh YX, Sherchan SP, Sirikanchana K, Smith W, Steele JA, Sabburg R, Symonds EM, Thai P, Thomas KV, Tynan J, Toze S, Thompson J, Whiteley AS, Wong JCC, Sano D, Wuertz S, Xagoraraki I, Zhang Q, Zimmer-Faust AG, Shanks OC. Minimizing errors in RT-PCR detection and quantification of SARSCoV-2 RNA for wastewater surveillance. Sci Total Environ. 2022; 805:149877. doi: 10.1016/j.scitotenv.2021.149877.

112. Bourke CD, Berkley JA, Prendergast AJ. Immune Dysfunction as a Cause and Consequence of Malnutrition. Trends Immunol. 2016;37(6):386-398. doi:10.1016/j.it.2016.04.003

113. Bloomfield SF, Stanwell-Smith R, Crevel RW, Pickup J. Too clean, or not too clean: the hygiene hypothesis and home hygiene. Clin Exp Allergy. 2006;36(4):402-425. doi:10.1111/j.1365-2222.2006.02463.x

114. Putignani L, Menichella D. Global distribution, public health and clinical impact of the protozoan pathogen cryptosporidium. Interdiscip Perspect Infect Dis. 2010;2010:753512. doi:10.1155/2010/753512

115. Ashigbie PG, Shepherd S, Steiner KL, Amadi B, Aziz N, Manjunatha UH, Spector JM, Diagana TT, Kelly P. Use-case scenarios for an anti-Cryptosporidium therapeutic. PLoS Negl Trop Dis. 2021;15(3):e0009057. doi: 10.1371/journal.pntd.0009057.

116. Miyamoto Y, Eckmann L. Drug Development Against the Major DiarrheaCausing Parasites of the Small Intestine, Cryptosporidium and Giardia. Front Microbiol. 2015;6:1208. doi: 10.3389/fmicb.2015.01208.

117. Putignani L, Menichella D. Global distribution, public health and clinical impact of the protozoan pathogen cryptosporidium. Interdiscip Perspect Infect Dis. 2010;2010:753512. doi:10.1155/2010/753512

118. Hawash Y, Dorgham LSh, Al-Hazmi AS, Al-Ghamdi MS. Prevalence of Cryptosporidium-associated diarrhea in a high altitude-community of Saudi Arabia detected by conventional and molecular methods. Korean J Parasitol. 2014 Oct;52(5):479-85. doi: 10.3347/kjp.2014.52.5.479. 
119. Hunter PR, Nichols G. Epidemiology and clinical features of Cryptosporidium infection in immunocompromised patients. Clin Microbiol Rev. 2002;15(1):145154. doi:10.1128/CMR.15.1.145-154.2002

120. Pedersen SH, Wilkinson AL, Andreasen A, Warhurst DC, Kinung'hi SM, Urassa M, Mkwashapi DM, Todd J, Changalucha J, McDermid JM. Cryptosporidium prevalence and risk factors among mothers and infants 0 to 6 months in rural and semi-rural Northwest Tanzania: a prospective cohort study. PLoS Negl Trop Dis. 2014;8(10):e3072. doi: 10.1371/journal.pntd.0003072.

121. Uppal B, Singh O, Chadha S, Jha AK. A comparison of nested PCR assay with conventional techniques for diagnosis of intestinal Cryptosporidiosis in AIDS cases from northern India. J Parasitol Res. 2014; 2014:706105. doi:10.1155/2014/706105

122. Kaushik K, Khurana S, Wanchu A, Malla N. Evaluation of staining techniques, antigen detection and nested PCR for the diagnosis of Cryptosporidiosis in HIV seropositive and seronegative patients. Acta Trop. 2008 Jul;107(1):1-7. doi: 10.1016/j.actatropica.2008.02.007.

123. Rossle NF, Latif B. Cryptosporidiosis as threatening health problem: A review. Asian Pac J Trop Biomed. 2013;3(11):916-924. doi:10.1016/S2221-1691(13)601793

124. Ursini T, Moro L, Requena-Méndez A, Bertoli G, Buonfrate D. A review of outbreaks of cryptosporidiosis due to unpasteurized milk. Infection. 2020;48(5):659-663. doi: 10.1007/s15010-020-01426-3.

125. Innes EA, Chalmers RM, Wells B, Pawlowic MC. A One Health Approach to Tackle Cryptosporidiosis. Trends Parasitol. 2020;36(3):290-303. doi:10.1016/j.pt.2019.12.016

126. Pignata C, Bonetta S, Bonetta S, Cacciò SM, Sannella AR, Gilli G, Carraro E. Cryptosporidium Oocyst Contamination in Drinking Water: A Case Study in Italy. Int J Environ Res Public Health. 2019;16(11):2055. doi: 10.3390/ijerph16112055.

127. Chalmers RM. Waterborne outbreaks of cryptosporidiosis. Ann Ist Super Sanita. 2012;48(4):429-46. doi: 10.4415/ANN_12_04_10.

128. Xiao S, An W, Chen Z, et al. The burden of drinking water-associated Cryptosporidiosis in China: the large contribution of the immunodeficient population identified by quantitative microbial risk assessment. Water Research. 2012 Sep;46(13):4272-4280. doi: 10.1016/j.watres.2012.05.012.

129. Food and Agriculture Organization (FAO) of the United Nations, and the World Health Organization (WHO). FAO/WHO Expert Meeting on Foodborne Parasites - Multicriteria-based ranking for risk management. Food Safety and Codex Unit Food and Agriculture Organization of the United Nations, Viale delle Terme di Caracalla 00153 Rome, Italy, and Department of Food Safety and Zoonoses, World Health Organization, 20 Avenue Appia, 1211 Geneva 27, Switzerland. WHO Press, World Health Organization, 20 Avenue Appia, 1211 Geneva 27, Switzerland. 2012. Available online at: https://www.fao.org/3/i3649e/i3649e.pdf [Accessed February 10, 2022] 
130. Ryan U, Hijjawi N, Xiao L. Foodborne cryptosporidiosis. Int J Parasitol. 2018 Jan;48(1):1-12. doi: 10.1016/j.ijpara.2017.09.004.

131. The World Bank. Bangladesh: Access to Clean Water Will Reduce Poverty Faster. 2018. Available at https://www.worldbank.org/en/news/pressrelease/2018/10/11/bangladesh-access-to-clean-water-will-reduce-poverty-faster [Accessed February 20, 2022]

132. UNICEF/WHO Report. 61.7 million deprived of basic hygiene facilities in Bangladesh: UN report. 2021. Available at https://www.msn.com/enxl/asia/bangladesh/617-million-deprived-of-basic-hygiene-facilities-inbangladesh-un-report/ar-AALFT3N [Accessed February 20, 2022]

133. Khan A, Shams S, Khan S, Khan MI, Khan S, Ali A. Evaluation of prevalence and risk factors associated with Cryptosporidium infection in rural population of district Buner, Pakistan. PLoS One. 2019;14(1): e0209188.

134. Quilez J, Sanchez-Acedo C, Avendaño C, del Cacho E, Lopez-Bernad F. Efficacy of two peroxygen-based disinfectants for inactivation of Cryptosporidium parvum oocysts. Appl Environ Microbiol. 2005;71(5):2479-83. doi: 10.1128/AEM.71.5.2479-2483.2005.

135. Chauret CP, Radziminski CZ, Lepuil M, Creason R, Andrews RC. Chlorine dioxide inactivation of Cryptosporidium parvum oocysts and bacterial spore indicators. Appl Environ Microbiol. 2001;67(7):2993-3001. doi: 10.1128/AEM.67.7.2993-3001.2001.

136. Naciri M, Mancassola R, Fort G, Danneels B, Verhaeghe J. Efficacy of aminebased disinfectant $\mathrm{KENO}^{\mathrm{TM}} \mathrm{COX}$ on the infectivity of Cryptosporidium parvum oocysts. Vet Parasitol. 2011;179(1-3):43-9. doi: 10.1016/j.vetpar.2011.01.066.

137. World Health Organization. Boil Water. Technical brief. WHO/FWC/WSH/15.02. 2015. Available at https://www.who.int/water sanitation health/dwq/Boiling water 01 15.pdf [Accessed February 20, 2022]

138. Fayer R. Cryptosporidium: a water-borne zoonotic parasite. Vet Parasitol. 2004;126(1-2):37-56. doi: 10.1016/j.vetpar.2004.09.004.

139. Lin A, Ercumen A, Benjamin-Chung J, Arnold BF, Das S, Haque R, Ashraf S, Parvez SM, Unicomb L, Rahman M, Hubbard AE, Stewart CP, Colford JM Jr, Luby SP. Effects of Water, Sanitation, Handwashing, and Nutritional Interventions on Child Enteric Protozoan Infections in Rural Bangladesh: A Cluster-Randomized Controlled Trial. Clin Infect Dis. 2018;67(10):1515-1522. doi: 10.1093/cid/ciy320.

140. Lin A, Arnold BF, Mertens AN, Lin J, Benjamin-Chung J, Ali S, Hubbard AE, Stewart CP, Shoab AK, Rahman MZ, Hossen MS, Mutsuddi P, Famida SL, Akther S, Rahman M, Unicomb L, Dhabhar FS, Fernald LCH, Colford JM Jnr, Luby SP. Effects of water, sanitation, handwashing, and nutritional interventions on telomere length among children in a cluster-randomized controlled trial in rural Bangladesh. Elife. 2017 Oct 5;6:e29365. doi: 10.7554/eLife.29365. 
141. Luby SP, Rahman M, Arnold BF, Unicomb L, Ashraf S, Winch PJ, Stewart CP, Begum F, Hussain F, Benjamin-Chung J, Leontsini E, Naser AM, Parvez SM, Hubbard AE, Lin A, Nizame FA, Jannat K, Ercumen A, Ram PK, Das KK, Abedin J, Clasen TF, Dewey KG, Fernald LC, Null C, Ahmed T, Colford JM Jr. Effects of water quality, sanitation, handwashing, and nutritional interventions on diarrhea and child growth in rural Bangladesh: a cluster randomized controlled trial. Lancet Glob Health. 2018;6(3):e302-e315. doi: 10.1016/S2214-109X(17)30490-4.

142. Guldan GS, Zeitlin MF, Beiser AS, Super CM, Gershoff SN, Datta S. Maternal education and child feeding practices in rural Bangladesh. Soc Sci Med. 1993 Apr;36(7):925-35. doi: 10.1016/0277-9536(93)90084-h.

143. Moore AC, Akhter S, Aboud FE. Responsive complementary feeding in rural Bangladesh. Soc Sci Med. 2006;62(8):1917-30. doi: 10.1016/j.socscimed.2005.08.058.

144. Todd ECD. Foodborne Diseases: Overview of Biological Hazards and Foodborne Diseases. Encyclopedia of Food Safety. 2014;221-242. doi:10.1016/B978-0-12-378612-8.00071-8

145. Schirone $M$, Visciano $P$, Tofalo $R$, Suzzi G. Biological Hazards in Food. Front Microbiol. 2017;7:2154. doi:10.3389/fmicb.2016.02154

146. Aniesona AT, Bamaiyi PH. Retrospective study of cryptosporidiosis among diarrhoeic children in the arid region of north-eastern Nigeria. Zoonoses Public Health. 2014 Sep;61(6):420-6. doi: 10.1111/zph.12088. Epub 2013 November 18. PMID: 24245998.

147. Ryan U, Fayer R, Xiao L. Cryptosporidium species in humans and animals: current understanding and research needs. Parasitology. 2014;141(13):1667-85. doi: 10.1017/S0031182014001085.

148. Delelegn MW, Endalamaw A, Belay GM. Determinants of Acute Diarrhea Among Children Under-Five in Northeast Ethiopia: Unmatched Case-Control Study. Pediatric Health Med Ther. 2020; 11:323-333. doi: 10.2147/PHMT.S256309.

149. Siregar AYM, Pitriyan P, Walters D. The annual cost of not breastfeeding in Indonesia: the economic burden of treating diarrhea and respiratory disease among children $(<24 \mathrm{mo})$ due to not breastfeeding according to recommendation. Int Breastfeed J. 2018; 13:10. doi: 10.1186/s13006-018-0152-2.

150. Turin CG, Ochoa TJ. The Role of Maternal Breast Milk in Preventing Infantile Diarrhea in the Developing World. Curr Trop Med Rep. 2014;1(2):97-105. doi:10.1007/s40475-014-0015-x

151. Korpe PS, Liu Y, Siddique A, Kabir M, Ralston K, Ma JZ, Haque R, Petri WA Jr. Breast milk parasite-specific antibodies and protection from amebiasis and Cryptosporidiosis in Bangladeshi infants: a prospective cohort study. Clin Infect Dis. 2013;56(7):988-92. doi: 10.1093/cid/cis1044. 
152. Abdel-Hafeez EH, Belal US, Abdellatif MZ, Naoi K, Norose K. Breastfeeding protects infantile diarrhea caused by intestinal protozoan infections. Korean J Parasitol. 2013;51(5):519-24. doi: 10.3347/kjp.2013.51.5.519.

153. Palmieri JR, Meacham SL, Warehime J, Stokes SA, Ogle J, Leto D, Bax M, Dauer AM, Lozovski JM. Relationships between the weaning period and the introduction of complementary foods in transmitting gastrointestinal parasitic infections in children in Honduras. Res Rep Trop Med. 2018:113-122. doi: 10.2147/RRTM.S160388.

154. Fawzy A, Arpadi S, Kankasa C, Sinkala M, Mwiya M, Thea DM, Aldrovandi GM, Kuhn L. Early weaning increases diarrhea morbidity and mortality among uninfected children born to HIV-infected mothers in Zambia. J Infect Dis. 2011;203(9):1222-30. doi: 10.1093/infdis/jir019.

155. Pumipuntu N, Piratae S. Cryptosporidiosis: A zoonotic disease concern. Vet World. 2018;11(5):681-686. doi:10.14202/vetworld.2018.681-686.

156. Olabanji GM, Maikai BV, Otolorin GR. Prevalence and Risk Factors Associated with Faecal Shedding of Cryptosporidium Oocysts in Dogs in the Federal Capital Territory, Abuja, Nigeria. Vet Med Int. 2016;2016:4591238. doi: $10.1155 / 2016 / 4591238$.

157. Chukwu VE, Daniels OO, Olorunfemi JC, Opara MN. Cryptosporidium oocysts: prevalence in dogs in Abuja, Federal Capital Territory, Nigeria. Ann Parasitol. 2019;65(4):321-327. doi: 10.17420/ap6504.216.

158. Koompapong K, Sukthana Y. Seasonal variation and potential sources of Cryptosporidium contamination in surface waters of Chao Phraya River and Bang $\mathrm{Pu}$ Nature Reserve pier, Thailand. Southeast Asian J Trop Med Public Health. 2012;43(4):832-40.

159. Mahgoub ES, Al Mahbashi A, Abdul Latif B. Cryptosporidiosis in children in a north Jordanian pediatric hospital. EMHJ-Eastern Mediterranean Health Journal, 10 (4-5), 494-501, 2004. 2004.

160. Robertson LJ, Johansen $\varnothing \mathrm{H}$, Kifleyohannes T, Efunshile AM, Terefe G. Cryptosporidium Infections in Africa-How Important Is Zoonotic Transmission? A Review of the Evidence. Front Vet Sci. 2020;7:575881. doi: 10.3389/fvets.2020.575881. 